OPEN ACCESS

Edited by:

David A. Sela,

University of Massachusetts Amherst,

United States

Reviewed by:

Nauman Khalid,

University of Management and

Technology, Lahore, Pakistan

Marco lammarino,

Istituto Zooprofilattico Sperimentale di

Puglia e Basilicata (IZSPB), Italy

*Correspondence:

Harjinder Singh

h.singh@massey.ac.nz

Specialty section

This article was submitted to

Food Chemistry,

a section of the journal

Frontiers in Nutrition

Received: 29 June 2020 Accepted: 02 September 2020

Published: 06 October 2020

Citation:

Roy D, Ye A, Moughan PJ and

Singh $H$ (2020) Composition,

Structure, and Digestive Dynamics of

Milk From Different Species - A

Review. Front. Nutr. 7:577759.

doi: 10.3389/fnut.2020.577759

\section{Composition, Structure, and Digestive Dynamics of Milk From Different Species-A Review}

\author{
Debashree Roy, Aiqian Ye, Paul J. Moughan and Harjinder Singh* \\ Riddet Institute, Massey University, Palmerston North, New Zealand
}

Background: The traditional dairy-cattle-based industry is becoming increasingly diversified with milk and milk products from non-cattle dairy species. The interest in non-cattle milks has increased because there have been several anecdotal reports about the nutritional benefits of these milks and reports both of individuals tolerating and digesting some non-cattle milks better than cattle milk and of certain characteristics that non-cattle milks are thought to share in common with human milk. Thus, non-cattle milks are considered to have potential applications in infant, children, and elderly nutrition for the development of specialized products with better nutritional profiles. However, there is very little scientific information and understanding about the digestion behavior of non-cattle milks.

Scope and Approach: The general properties of some non-cattle milks, in comparison with human and cattle milks, particularly focusing on their protein profile, fat composition, hypoallergenic potential, and digestibility, are reviewed. The coagulation behaviors of different milks in the stomach and their impact on the rates of protein and fat digestion are reviewed in detail.

Key findings and Conclusions: Milk from different species vary in composition, structure, and physicochemical properties. This may be a key factor in their different digestion behaviors. The curds formed in the stomach during the gastric digestion of some non-cattle milks are considered to be relatively softer than those formed from cattle milk, which is thought to contribute to the degree to which non-cattle milks can be easily digested or tolerated. The rates of protein and fat delivery to the small intestine are likely to be a function of the macro- and micro-structure of the curd formed in the stomach, which in turn is affected by factors such as casein composition, fat globule and casein micelle size distribution, and protein-to-fat ratio. However, as no information on the coagulation behavior of non-cattle milks in the human stomach is available, in-depth scientific studies are needed in order to understand the impact of compositional and structural differences on the digestive dynamics of milk from different species.

Keywords: milk, composition, digestion, curd, protein, fat, structure, stomach 


\section{INTRODUCTION}

Milk has evolved to meet the nutritional and physiological requirements of the neonate. Milk is thus regarded as a highquality food, nutritionally. Humans are known to have consumed cattle (Bos taurus, cow) and non-cattle (such as goat and sheep) milks as part of their diet since prehistoric times $(1,2)$. As a convenient source of nutrition, cattle milk is the mostconsumed milk worldwide because of its widespread availability and large production volumes. Non-cattle milks are of nutritional importance to people in developing countries as well as in geographical areas in which the natural climate is unsuitable for the survival of dairy cattle $(3,4)$. For example, buffalo milk in Asia, sheep milk in Europe and the Mediterranean basin (including the Middle East), camel milk ("the white gold of the desert") in Africa, goat milk ("the cattle of the poor") in Africa and southern Asia, horse milk in the steppe areas of central Asia, yak milk on the Tibetan plateau, reindeer milk in northern Scandinavia, musk ox milk in the Arctic, and mithun milk in the hilly regions of the Indian subcontinent $(3,5)$.

Of the total world milk production, the proportion of total non-cattle milk production has increased from $~ 9 \%$ in 1961 to $19 \%$ in 2018 (Figure 1). Of the total global non-cattle milk production, buffalo milk has nearly tripled, camel milk has nearly doubled, and goat milk has slightly increased during this period. No world statistics on the amounts of milk produced from other dairy species, such as yak, horse, donkey, deer, musk ox, and llama, are available. Much of the non-cattle milk production remains officially unreported because of the unknown amounts that are consumed locally at a farmer's home or are sold directly by farmers to local people, especially in developing countries $(6,7)$.

The addition of milk as a product to non-cattle farm systems adds value and helps farmers in dealing with the fluctuating prices of meat, hair, and wool. The buffalo, goat, sheep, and camel milking industry is well set-up in many parts of the world, is gaining popularity, and is proving to be a profitable business for those who have already implemented it. Recently, New Zealand has introduced the development of a red deer dairy farming system. Large dairy companies as well as specialized small and medium enterprises (SMEs) are also interested in using non-cattle milks as a diversification strategy for their product portfolios. The regulatory requirements to ensure the safe production of cattle milk (and milk products) are well-defined in most of the world. However, the same regulatory limits may not be true to non-cattle milk and milk products. Thus, the emphasis on species-specific regulatory standards to guarantee the safety and quality of different milk for human consumption is needed (8-11). Also, understanding the significance of compliance to religious dietary laws (such as Kosher or Halal) will be of importance to the non-cattle milk-based dairy companies for gaining acceptance of their products from the various consumer groups (12).

In recent years, the opportunities for non-cattle milk production and the manufacture of products have expanded because the numbers of dairy cattle are perceived to be reaching their limit from environmental perspectives. Non-cattle milks are also believed to have certain nutritional benefits compared with cattle milks. For example, goat, sheep, camel, horse, and donkey milk are considered to be relatively more easily digestible, less allergenic, and more similar to human milk than cattle milk $(4,13,14)$. In addition, non-cattle milks can be utilized for developing high value specialized dairy products of international as well as regional (local cultural) importance, such as cheese, yogurt, butter, ghee, ice-cream, fermented milk, probiotic dairy drinks, milk tablets, infant formulas $(3,15,16)$. However, relatively little scientific information on the nutritional benefits of non-cattle milks is available. In addition, there is a significant gap in scientific knowledge on the detailed compositions, especially the minor components, and the protein and lipid structures in these milks.

\section{COMPARATIVE COMPOSITIONS OF CATTLE AND NON-CATTLE MILKS}

The comparative compositions of milk from different species have been extensively reviewed in previous studies (5, 17-19). The milk from different species vary in composition (Table 1). Protein, fat, lactose, and minerals are the four major components in all milks, irrespective of the species (18); the composition of milk within the same species varies considerably because of various factors, such as breed, stage of lactation, milking interval, type of feed, and climate $(7,19)$. For example, Li et al. (26) reported recently that the stage of lactation is a key factor responsible for differences in the compositional and physicochemical properties of dairy cattle milk in a seasonal calving system in New Zealand.

Non-ruminant milks (such as those from horse and donkey) are somewhat similar to human milk (in terms of protein, lactose, and ash contents), compared with dairy cattle milk and other ruminant milks (Table 1). Ruminant milks have higher protein and fat contents, compared with human milk and other nonruminant milks. Human milk contains much higher amounts of total lactose-derived oligosaccharides than milk from other species (Table 1). Goat milk is also known to have a relatively higher oligosaccharide content, the composition of which is considered to be similar to that of human milk $(27,28)$.

\section{Proportions of Major Proteins}

Compared with cattle milk and other ruminant milks, horse and donkey milk have a low casein-to-whey-protein ratio, similar to that in human milk. Among the ruminant milks, goat, sheep, and camel milk have a lower casein-to-whey-protein ratio as well as a relatively higher $\beta$-casein-to- $\alpha_{\mathrm{s}}$-casein ratio compared with cattle milk (Table 2). Thus, these non-cattle milks are an attractive alternative as a potential natural ingredient for infant formula (13); a lower casein-to-whey-protein ratio (i.e., a higher proportion of whey proteins) has been shown to be more desirable for faster digestion of the milk proteins in infant formula than a casein-dominant protein composition $(31,32)$. As human milk has the lowest casein-to-whey-protein ratio, has a high $\beta$-casein-to- $\alpha_{s}$-casein ratio, and contains no $\beta$-lactoglobulin (Table 2), milk from other species with similar properties are of 
A

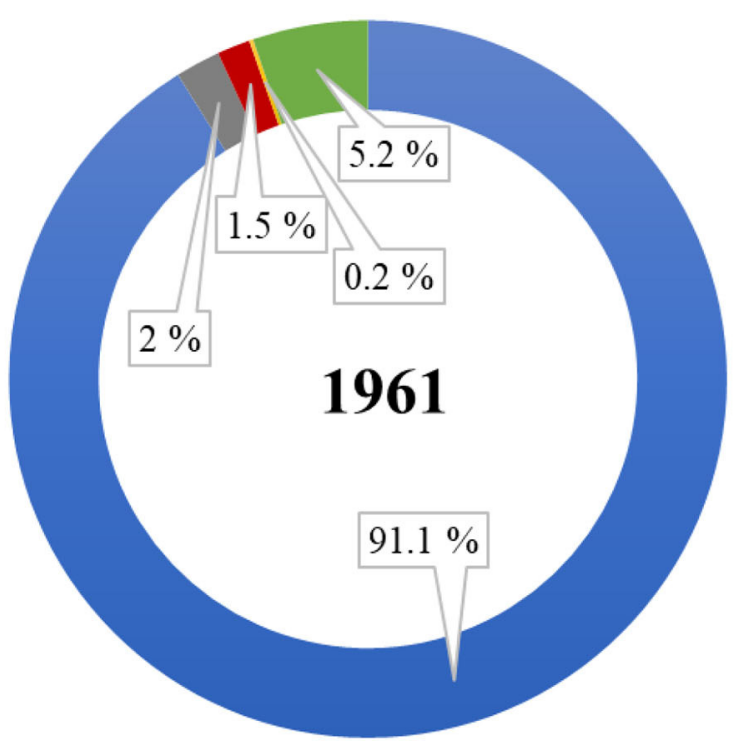

- Cattle milk $\backsim$ Goat milk $\backsim$ Sheep milk $\backsim$ Camel milk $\backsim$ Buffalo milk

B

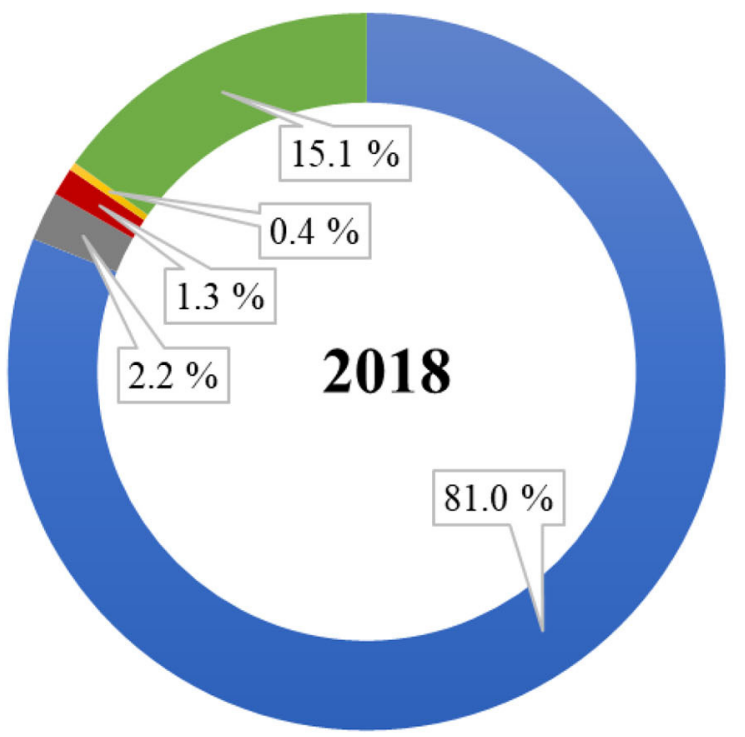

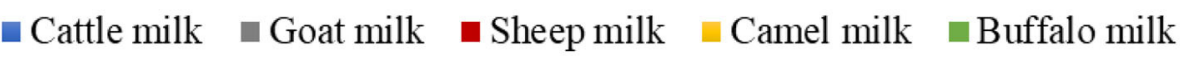

FIGURE 1 | Proportion of dairy cattle and non-cattle milks produced globally in the year (A) 1961 and (B) 2018. (Source: FAOstat, March 2020).

great interest to the consumer as well as to the dairy industry for the development of specialized dairy products, not only for infants but also for people in other age groups.

$\beta$-Lactoglobulin is considered to be one of the major allergens that is responsible for cattle milk allergy in children (33). Thus, milk from species that lack $\beta$-lactoglobulin or have lower $\beta$ lactoglobulin-to- $\alpha$-lactalbumin ratios are of interest for human consumption. Camel milk, like human milk, does not contain $\beta$-lactoglobulin $(34,35)$ or it may be present in trace amounts in different forms (36-38). Llama milk is also known to contain no $\beta$-lactoglobulin $(5,39)$, but little detailed information on its protein composition is available.

\section{Casein Micelle Characteristics}

Individual caseins $\left(\alpha_{\mathrm{s} 1^{-}}, \alpha_{\mathrm{s} 2^{-}}, \beta\right.$-, and $\left.\kappa_{\text {-casein }}\right)$ are present in all milks as self-assembled particles known as "casein micelles" 
TABLE 1 | General composition ( $\mathrm{g} 100 \mathrm{~mL}^{-1}$ ) of milk from different mammalian species\#.

\begin{tabular}{|c|c|c|c|c|c|c|c|c|c|}
\hline \multirow[b]{2}{*}{ Properties } & \multicolumn{6}{|c|}{ Ruminants } & \multicolumn{2}{|c|}{ Non-ruminants } & \multirow[t]{2}{*}{ Human } \\
\hline & Cattle & Buffalo & Goat & Sheep & Red deer* & Camel & Horse & Donkey & \\
\hline Total solids & $11.8-13.0$ & $15.7-17.2$ & $11.9-16.3$ & $18.1-20.0$ & 20.0-30.5 & $11.9-15.0$ & $9.3-11.6$ & $8.8-11.7$ & $10.7-12.9$ \\
\hline Protein & $3.0-3.9$ & $2.7-4.7$ & $3.0-5.2$ & $4.5-7.0$ & $5.9-10.6$ & $2.4-4.2$ & $1.4-3.2$ & $1.4-2.0$ & $0.9-1.9$ \\
\hline Fat & $3.3-5.4$ & $5.3-9.0$ & $3.0-7.2$ & $5.0-9.0$ & $6.6-19.7$ & $2.0-6.0$ & $0.3-4.2$ & $0.3-1.8$ & $2.1-4.0$ \\
\hline Lactose & $4.4-5.6$ & $3.2-4.9$ & $3.2-5.0$ & $4.1-5.9$ & $2.6-6.2$ & $3.5-5.1$ & $5.6-7.2$ & $5.8-7.4$ & $6.3-7.0$ \\
\hline Ash & $0.7-0.8$ & $0.8-0.9$ & $0.7-0.9$ & $0.8-1.0$ & $1.04-1.18$ & $0.69-0.9$ & $0.3-0.5$ & $0.3-0.5$ & $0.2-0.3$ \\
\hline Oligosaccharides ${ }^{\Omega}$ & $0.003-0.006$ & No data & $0.025-0.030$ & $0.002-0.004$ & No data & No data & No data & No data & $0.500-0.800$ \\
\hline
\end{tabular}

\# Source: Adapted and modified from Claeys et al. (19) and Crowley et al. (13).

*Values based on minimum and maximum values found in the literature for different species of red deer; may include values from different stages of lactation (20-24).

$\Omega$ Values derived from Martinez-Ferez et al. (25).

TABLE 2 | Protein profile $\left(\mathrm{g} \mathrm{L}^{-1}\right)$ of milk from different mammalian species\#.

\begin{tabular}{|c|c|c|c|c|c|c|c|c|c|}
\hline \multirow[b]{2}{*}{ Protein fractions } & \multicolumn{6}{|c|}{ Ruminants } & \multicolumn{2}{|c|}{ Non-ruminants } & \multirow[t]{2}{*}{ Human } \\
\hline & Cattle & Buffalo & Goat & Sheep & Red deer* & Camel & Horse & Donkey & \\
\hline Total casein & $24.6-28$ & $32-40$ & $23.3-46.3$ & $41.8-52.6^{\infty}$ & $\sim 57-84$ & $22.1-26.0$ & $9.4-13.6$ & $6.4-10.3$ & $2.4-4.2$ \\
\hline Total whey proteins & $5.5-7.0$ & 6 & $3.7-7.0$ & $10.2-16.1^{\infty}$ & $\sim 11-15$ & $5.9-8.1$ & $7.4-9.1$ & $4.9-8.0$ & $6.2-8.3$ \\
\hline Casein-to-whey protein ratio & $82: 18$ & $82: 18$ & $78: 22$ & $76: 24$ & 80:20-85:15 & $73: 27-76: 24$ & $52: 48$ & $56: 44$ & 29:71-33:67 \\
\hline \multicolumn{10}{|l|}{ Major caseins } \\
\hline$\alpha_{s 1}$-Casein & $8-10.7$ & 8.9 & $0-13.0$ & $2.4^{\infty}-22.1$ & - & $4.9-5.7^{\Omega}$ & 2.4 & Present & 0.77 \\
\hline$\alpha_{\mathrm{s} 2}$-Casein & $2.8-3.4$ & 5.1 & $2.3-11.6$ & $6.0^{\infty}$ & - & $2.1-2.5^{\Omega}$ & 0.2 & Present & Absent \\
\hline$\beta$-Casein & $8.6-9.3$ & $12.6-20.9$ & 0-29.6 & $15.6-39.6^{\infty}$ & - & $14.4-16.9^{\Omega}$ & 10.66 & Present & 3.87 \\
\hline$\kappa$-Casein & $2.3-3.3$ & $4.1-5.4$ & $2.8-13.4$ & $3.2-12.23^{\infty}$ & - & $0.8-0.9^{\Omega}$ & 0.24 & Present & 0.14 \\
\hline \multicolumn{10}{|l|}{ Major whey proteins } \\
\hline$\beta$-Lactoglobulin & $3.2-3.3$ & 3.9 & $1.5-5.0$ & $6.5-13.5^{\infty}$ & - & Absent & 2.55 & 3.3 & Absent \\
\hline$\alpha$-Lactalbumin & $1.2-1.3$ & 1.4 & $0.7-2.3$ & $1-1.9$ & - & $0.8-3.5$ & 2.37 & 1.9 & $1.9-3.4$ \\
\hline
\end{tabular}

\# Source: Adapted and modified from Claeys et al. (19) and Crowley et al. (13).

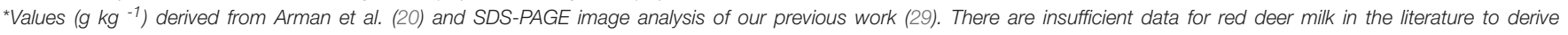
approximate values.

${ }^{\Omega}$ Values derived from Kappeler (30).

${ }^{\infty}$ Values $\left(\mathrm{g} \mathrm{kg}^{-1}\right)$ derived from SDS-PAGE image analysis of our previous work (29).

(40). The fundamental structure of the casein micelles in the milk from many species has not been studied in great detail, except in dairy cattle milk. Recently, Ingham et al. (41) used small-angle X-ray scattering and reported that the internal structures of the casein micelles of cattle, goat, and sheep milk had strong similarities with only slight differences, which may be due to the differences in casein composition, hydration, and physicochemical properties.

Apart from the differences in the proportions of different caseins (Table 2), the casein micelles in the milk from different species differ in size, hydration, and mineralization (Table 3). Among all mammalian milks, the casein micelles in human milk have the smallest diameter. The casein micelle sizes of goat, sheep, deer, camel, and horse milk are larger than that of human milk as well as cattle milk (Table 3). Sood et al. (53) reported that the loss of micellar calcium from the skim milk casein micelles (when dialyzed against same skim milk sample containing ethylenediaminetetraacetic acid, EDTA) resulted in increased hydration (or swelling) of casein micelles. Based on this, it was considered that the hydration level of the casein micelles was negatively correlated with mineralization of micelles (54) i.e., when the mineralization of the casein micelle increases, the degree of hydration of casein micelle decreases. Thus, the lower hydration of goat and sheep milk casein micelles had been related to its higher mineralization than those of cattle milk casein micelles $(55,56)$. Similarly, the casein micelles in buffalo milk (50) and donkey milk (51) are considered to be less hydrated and more mineralized than those in cattle milk.

It should be highlighted that there is a high degree of variation in the results that have been reported for the casein micelle characteristics within the same species, which may be due to differences in the analytical methods used. In addition, differences in breeds, genetic variants, and phosphorylation sites of the caseins may also add to the variation in the characteristics of the casein micelles within and across species (13).

\section{Milk Fat Composition}

Compared with milk fat from other species (especially ruminants), human milk fat contains lower proportions of saturated fatty acids, higher proportions of monounsaturated 
TABLE 3 | Casein characteristics of milk from different mammalian species ${ }^{\#}$.

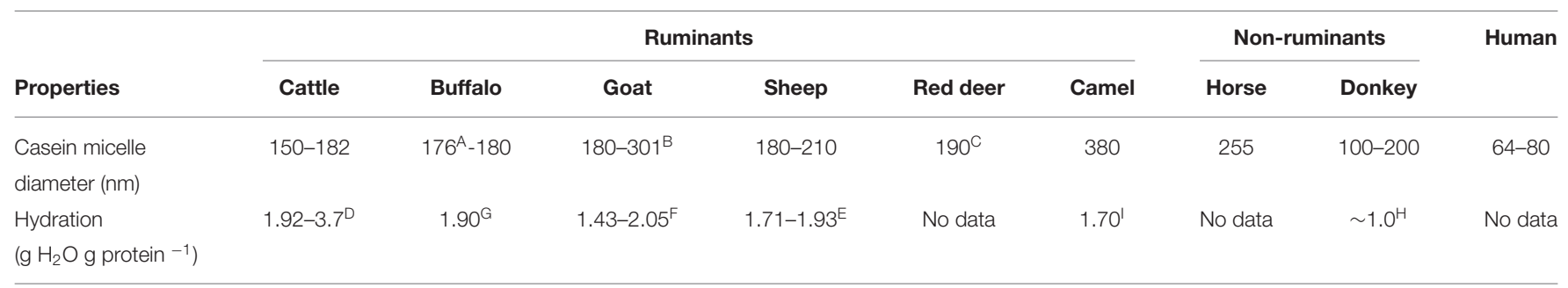

\# Source: Adapted and modified from Claeys et al. (19).

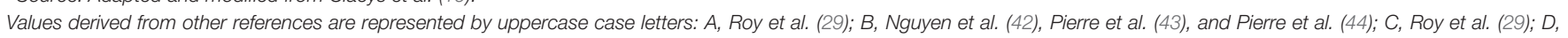
Dalgleish (45), Wang et al. (46), and Dewan et al. (47); E, Pellegrini et al. (48); F, Remeuf et al. (49); G, Ahmad et al. (50); H, Luo et al. (51); I, Beaucher et al. (52).

fatty acids and polyunsaturated fatty acids, a higher ratio of $\omega-6$ to $\omega-3$ fatty acids, and higher levels of cholesterol (Table 4). In general, horse and donkey milk contain lower proportions of saturated fatty acids and higher proportions of polyunsaturated fatty acids than ruminant milks. In contrast, ruminant milks contain higher proportions of monounsaturated fatty acids, a higher ratio of $\omega-6$ to $\omega-3$ fatty acids, and a higher cholesterol content than horse and donkey milk (Table 4). The conjugated linoleic acid content is similar in human and ruminant milks but is lower in non-ruminant milks (Table 4).

Sheep and goat milk fats are known to be rich in short chain (responsible for the distinct flavor of these milks) and medium chain triacylglycerols (TAGs); similarly, buffalo milk fat contains higher proportions of medium chain TAGs than cattle milk, which has high proportions of long chain TAGs (57-60). In contrast, camel milk contains a higher proportion of long chain fatty acids and a lower proportion of short chain fatty acids than cattle milk (61). Data for the fat composition of red deer milk are scarce, but this milk is considered to contain $5-10 \%$ fewer unsaturated fatty acids and higher proportions of shorter chain and saturated fatty acids than cattle milk (21). These differences may contribute to the different digestion behaviors of the milk fat from different species, as short or medium chain TAGs are considered to be more efficiently hydrolyzed by lipases $(62,63)$.

Free long chain saturated fatty acids, such as palmitic acid (C16:0), are not considered to be efficiently absorbed in the body as they form insoluble fatty soaps with calcium in the small intestine $(64,65)$. In this context, the TAG structure is considered to play a key role. Most of the long chain palmitic acid (C16:0) present in human milk $(>70 \%)$ is located in the sn-2 position of the TAG structure; this position is considered to be suitable for the digestion and absorption of this fatty acid as well as other nutrients $(18,62,66)$. German and Dillard (64) stated that the location of saturated fatty acids, such as long chain palmitic acid on the sn-2 position of TAGs, makes both the sn-1 and the sn3 position fatty acids easily hydrolyzable by pancreatic lipases into free fatty acids, and produces sn-2 monoacylglycerols, which are easily absorbed in the small intestine; this also makes the milk calcium completely available and absorbable. Donkey milk has the closest proportion of palmitic acid located at the sn-2 position (i.e., 54\%) to that of human milk (74\%) (Table 4). Thus, the modification of the TAG structure in milk from other species may help to deliver better milk fat digestion profiles; this could be an area of future interest.

\section{Milk Fat Globule Size}

The fat in the milk of all species is present as small spherical droplets, called globules, the diameter of which ranges from 0.2 to $15 \mu \mathrm{m}$ (67). The size of these fat globules varies among milk from different species; goat, sheep, camel, and equine (horse and donkey) milk have higher proportions of smaller size fat globules compared to cattle milk (Table 5). The differences in the sizes of the fat globules of milk from different species may influence the digestion of their fat differently $(18,19)$. The TAG core of the fat globules from all species is surrounded, protected, and stabilized by a phospholipid trilayer (along with specific membrane proteins) called the milk fat globule membrane (MFGM) $(68,69)$. The MFGM is unique to milk and its structure is considered to be similar in all milks, although the proportions of different proteins in the MFGM may differ among different species (70).

In general, the differences in the characteristics of the casein micelles and the fat globules among different milks are considered to play important roles in influencing their coagulation behavior and nutrient delivery during digestion, which is discussed in the section on milk digestion.

\section{HYPOALLERGENIC POTENTIAL OF NON-CATTLE MILKS}

More than 20 proteins in cattle milk are known to cause allergic reactions; of these, the casein fractions (especially $\alpha_{\mathrm{s} 2^{-}}, \alpha_{\mathrm{s} 1^{-}}$, and $\kappa$-caseins as well as, to some extent, $\beta$-casein), lactoferrin, serum albumin, and $\beta$-lactoglobulin are considered to be the most common cattle milk allergens (71-73).

There is increasing interest with respect to the suitability of non-cattle milks as a hypoallergenic option to cattle milk (74). A few studies have reported that horse milk (75), donkey milk $(76,77)$, camel milk $(78,79)$, and water buffalo milk $(80)$ may be potential alternatives in cases of moderate allergenicity to cattle milk in children; however, this needs to be further investigated because weak cross-reactivity of non-cattle milk proteins with cattle milk proteins has been reported (81-83). Jenkins et al. (71) conducted a comprehensive study on the cross-reactivity of human and non-human milk proteins and found that the 
TABLE 4 | Fatty acid profile (\% of total fatty acids) and cholesterol content of milk from different mammalian species ${ }^{\#}$.

\begin{tabular}{|c|c|c|c|c|c|c|c|c|c|}
\hline \multirow[b]{2}{*}{ Fatty acids } & \multicolumn{6}{|c|}{ Ruminants } & \multicolumn{2}{|c|}{ Non-ruminants } & \multirow[t]{2}{*}{ Human } \\
\hline & Cattle & Buffalo & Goat & Sheep & Red deer & Camel & Horse & Donkey & \\
\hline SFA (\%) & $55.7-72.8$ & $62.1-74$ & $59.9-73.7$ & $57.5-74.6$ & No data & $47-69.9$ & $37.5-55.8$ & $46.7-67.7$ & $39.4-45$ \\
\hline MUFA (\%) & $22.7-30.3$ & $24.0-29.4$ & $21.8-35.9$ & 23.0-39.1 & No data & $28.1-31.1$ & 18.9-36.2 & $15.31-35.0$ & $33.2-45.1$ \\
\hline PUFA (\%) & $2.4-6.3$ & $2.3-3.9$ & $2.6-5.6$ & $2.5-7.3$ & No data & $1.8-11.1$ & $12.8-51.3$ & $14.17-30.5$ & $8.1-19.1$ \\
\hline$\omega-6: \omega-3$ fatty acids ratio & $2.1-3.7$ & No data & 4 & $1.0-3.8$ & No data & No data & $0.3-3.5$ & $0.9-6.1$ & $7.4-8.1$ \\
\hline CLA (\%) & $0.2-2.4$ & $0.4-1$ & $0.3-1.2$ & $0.6-1.1$ & No data & $0.4-1$ & $0.02-0.1$ & No data & $0.2-1.1$ \\
\hline Cholesterol (mg/100 mL milk) & $13.1-31.4$ & $4-18.0$ & $10.7-18.1$ & $14-29.0$ & No data & $31.3-37.1$ & $5.0-8.8$ & No data & $14-20$ \\
\hline$\%$ of $\mathrm{C} 16: 0$ at sn-2 & 38 & 37 & 36 & 29 & No data & No data & No data & 54 & 74 \\
\hline
\end{tabular}

\#Source: Adapted and modified from Claeys et al. (19) and Crowley et al. (13).

SFA, saturated fatty acids; MUFA, monounsaturated fatty acids; PUFA, polyunsaturated fatty acids; CLA, conjugated linoleic acid, C16:0, palmitic acid on the sn-2 position of milk TAG.

TABLE 5 | Fat globule size of milk from different mammalian species\#.

\begin{tabular}{|c|c|c|c|c|c|c|c|c|c|}
\hline \multirow[b]{2}{*}{ Property } & \multicolumn{6}{|c|}{ Ruminants } & \multicolumn{2}{|c|}{ Nonruminants } & \multirow[t]{2}{*}{ Human } \\
\hline & Cattle & Buffalo & Goat & Sheep & Red deer & Camel & Horse & Donkey & \\
\hline Fat globule diameter ( $\mu \mathrm{m})$ & $2.8-4.6$ & $4.1-8.7$ & $2.6-3.7^{\mathrm{A}}$ & $3.0-4.6$ & $2.7-6.6^{A}$ & 3.0 & $2-3$ & $1-10$ & 4 \\
\hline
\end{tabular}

\# Source: Adapted and modified from Claeys et al. (19) and Crowley et al. (13).

Values derived from other references are represented by uppercase case letters: A, Roy et al. (29).

degree of allergenicity of a non-human milk protein is related to its extent of similarity with its human homologs. They found that, compared with cattle, goat, and sheep milk proteins, camel and horse milk proteins (i.e., $\alpha_{s 1^{-}}$and $\beta$-caseins) are more homologous to their human milk counterparts, which may be a reason for their weak cross-reactivity or less allergenic nature compared with other non-cattle milks.

Infante et al. (84) reported that $25 \%$ of patients had a negative immunological test for adverse reactions to goat milk proteins; thus, goat milk cannot be considered to be a suitable alternative in cases of cattle milk allergy. Similarly, there is also strong evidence of allergenicity or positive cross-reactivities of goat, sheep, deer, and buffalo milk with cattle milk $(83,85-87)$. In addition, reports concerning selective allergy to goat and sheep milk proteins, but not to cattle milk proteins, are also available $(88,89)$. Bevilacqua et al. (90) found that goat milk with lower proportions of $\alpha s_{1}$ casein (and higher amounts of $\alpha s_{2}$-casein) was significantly less allergenic in guinea pigs than goat milk with high $\alpha_{s 1}$-casein content (and low $\alpha_{\mathrm{s} 2}$-casein content); thus, different proportions of milk proteins may also play a key role in controlling milk protein allergy.

Overall, the scientific evidence indicates that there is little basis for promoting non-cattle milk or milk proteins as an alternative to cattle milk for people suffering from cattle (or cow) milk allergy.

\section{MILK DIGESTION}

\section{Indispensable Role of the Gastric Phase in Milk Digestion}

It is well-accepted that milk is a source of nutritionally balanced and highly digestible proteins $(91,92)$. Previous studies have reported that the gastric emptying rates of two major fractions of milk protein (i.e., casein and whey protein) differ markedly; this has led to the concept of "slow" digested caseins and "fast" digested whey proteins (93-98).

The digestion of milk by the stomach enzymes (mainly pepsin and, to some extent, gastric lipases) in the presence of hydrochloric acid is considered to be the first key step, which is followed by further digestion in the small intestine by intestinal proteases and lipases $(99,100)$. Some human infants may have chymosin like enzyme along with pepsin, which disappears from the gastric fluid by day 11 after birth (101). Chymosin and pepsin belong to the same group of aspartic proteinases that uses aspartic acid residues in their active center (102). Both the enzymes can preferentially hydrolyze the Phe105-Met106 bond of $\kappa$-casein, except that pepsin also exhibits unspecific proteolytic activity toward bonds with Trp, Tyr, Leu or Val residues, and thus have higher proteolytic activity relative to its milk clotting activity than chymosin (102-104). As the site of action of both chymosin and pepsin is the same, the mechanism of action of chymosin and pepsin is expected to be similar in relation to milk clotting. Chymosin is most stable in the $\mathrm{pH}$ range 5.3-6.3, but loses its

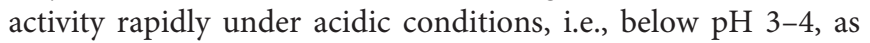
well as at high alkaline $\mathrm{pH}$ values, i.e., above $\mathrm{pH} 9.8$ (105). Pepsin has maximum proteolytic activity at $\mathrm{pH} 2$, with an optimum $\mathrm{pH}$ range of $2-5$, and has activity in the $\mathrm{pH}$ range $\mathrm{pH} 5.5-7.5$. Pepsin is irreversibly inactivated at pHs above 7.5 (106).

The protein hydrolysis sites of pepsin are different from those of the intestinal proteases (mainly trypsin and chymotrypsin). Pepsin acts preferentially on $\kappa$-casein on the casein micelles, leading to the coagulation of the casein fraction of milk proteins under acidic conditions, whereas the whey protein fraction remains soluble (107). Thus, the early role played by the stomach 
in milk digestion is an essential step in regulating the rate of digestion of the milk proteins in the gastrointestinal tract (108). In this respect, it is of great importance to understand the digestive dynamics and coagulation behavior of milk during gastric digestion, as milk coagulation can influence the delivery rates of proteins, fats, and associated milk constituents.

\section{Evidence of Milk Coagulation}

Human milk is known to form very soft and fragile curds in the infant stomach. Mason (109) investigated the changes in $\mathrm{pH}$ and the extent of protein hydrolysis in the stomach contents collected using a gastric tube at different time intervals from 25 healthy newborn infants (full-term, aged between 5 and 13 days). He reported the presence of casein curds in the stomach contents collected after $30 \mathrm{~min}$ of breastfeeding. He also reported that there was negligible protein hydrolysis in these samples. Similarly, recently, de Oliveira et al. (110) studied the gastric digestion of raw and pasteurized human milk in tube-fed preterm infants. The microstructural analysis in their study showed that human milk formed very soft and fragile protein aggregates in the infant's stomach.

Piglets and growing pigs have been regarded as a suitable animal model for human digestion research (111-113). Bottlefed piglets have been used to study the digestion of human milk and infant formulas (114-116). Some evidence of clot (or curd) formation by cattle milk in pigs or piglets has been reported in the literature. Washburn and Jones (117) reported that cattle skim milk formed a tough or hard clot, whereas cattle whole milk formed a more friable and mellow curd in the stomach of baby pigs (28-35 days old), and that, the higher the fat content, the softer was the curd that formed. Braude et al. (118) found that the caseins from homogenized cattle milk clotted in the stomach of the 28-day-old pig after 15-30 min of feeding, whereas the "whey" fraction of the milk remained soluble and passed rapidly into the small intestine. Similarly, Decuypere et al. (119) reported the formation of firm casein clots in the stomachs of early weaned pigs (10-29 days of age) fed dry cattle-milk-based food; their gastric chyme had a long retention time and a low buffering capacity and stimulated more gastrin release, compared with the gastric contents of suckling piglets fed pig milk. They believed that these differences were due to the firm casein clot formed by a dry cattle-milk-based food in early weaned pigs in comparison with the soft casein aggregate formed from pig milk in suckling piglets.

\section{Clotting Characteristics of Human Milk and Cattle Milk and Its Implications}

Cattle milk is known to form firm curds (or clots) in the stomach, in comparison with human milk.

Nakai and Li-Chan (108) studied the coagulation characteristics of human and cattle milk using an in vitro acid precipitation test at $37^{\circ} \mathrm{C}$, in which they added $0.2 \%$ acidic pepsin solution to $100 \mathrm{~mL}$ each of cattle milk and human milk at a flow rate of $15 \mathrm{~mL} / \mathrm{h}$. They found that human milk formed much finer protein aggregates (or clots) than cattle milk and reported that this could be the possible reason for the shorter gastric emptying time for human milk.
The differences in the structures of human and cattle milk curds could be related to the differences in their fat and protein compositions. The protein (casein)-to-fat ratio of human milk is very low (Tables 1,2 ) compared with that of cattle milk (as well as of other non-cattle milks), which is likely to be a factor that is responsible for its soft (or fragile) curd formation. In addition, the higher $\beta$-casein-to- $\alpha_{s}$-casein ratio of human milk has been associated with the fine and loose curd formed by human milk in an infant stomach. Lichan and Nakai (120) performed an in vitro coagulation study with untreated cattle milk casein, rennin-modified cattle milk casein, and human milk casein. The rennin-modified cattle milk casein was a $\beta$-casein-rich cattle milk (similar to $\beta$-casein-rich human milk) that was produced by selectively eliminating the $\alpha_{s 1}$-casein fraction from cattle milk by a process involving rennet action. Upon acidification of the different casein solutions to $\mathrm{pH} 2$ or $\mathrm{pH} 4$, Lichan and Nakai (120) observed that the hardness of the clot formed from these different casein solutions decreased in the order: cattle milk casein $>$ rennin-modified cattle milk casein (rich in $\beta$-casein) $>$ human casein. In another study, Lichan and Nakai (121) also reported that moderate or partial dephosphorylation of cattle milk casein using different phosphatases (calf intestinal alkaline phosphatase and potato acid phosphatase) at $\mathrm{pH} 4$ resulted in the acid-coagulating properties of these modified cattle milk casein solutions being similar to those of human milk as well as in a greater rate of proteolysis compared with the firm clots of untreated cattle milk casein. However, all these studies were in vitro physicochemical studies, and further studies in in vitro or in vivo digestion models need to be conducted to validate such findings.

Blakeborough et al. (122) studied the digestion of human milk, cattle milk, and reconstituted baby formula (based on full cream dry cattle milk powder) using 14-day-old piglets; cattle milk or baby formula formed firm solid curds, whereas human milk formed a very liquid-like coagulum (little solid material) in the piglet's upper gastrointestinal tract. They also determined the bioavailability of zinc ( $\mathrm{Zn})$ from these milk systems; they found that, for cattle milk (as well as baby formula), $\sim 55-$ 72 and $\sim 60-66 \%$ of the $\mathrm{Zn}$ was retained in the curds present in the gastric chyme and the intestinal digesta, respectively, whereas, for human milk, $\sim 43$ and $7 \%$ of the $\mathrm{Zn}$ was retained in the curds present in the gastric chyme and the intestinal digesta, respectively. They suggested that these differences in the distribution and bioaccessibility of $\mathrm{Zn}$ in the gastrointestinal tract of piglets fed human milk or cattle milk may have been due to the differences found in the consistency of the casein curds formed by the different milks.

\section{Digestion of Milk From Different Species Protein Digestion}

The lower protein content, lower casein-to-whey-protein ratio, and higher $\beta$-casein-to- $\alpha_{\mathrm{s}}$-casein ratio of human milk compared with milk from other species have been related to its soft curdling properties in vitro as well as in vivo, as described earlier. Although none of the non-human milks match the composition of human milk, horse, and donkey milk are known to form very weak or fragile gels (or curds or flocs) when acidified or treated with 
rennet (123-125) and thus are expected to form soft or fragile curds in the stomach, in comparison with cattle milk, because of their lower casein content. Similarly, some of the ruminant milks, such as goat and camel milk (126-130), are also considered to form soft curds in the stomach when acidified or treated with rennet (or pepsin), because of their lower casein content or larger casein micelle size compared with cattle milk, even though they contain comparatively higher proportions of caseins than equine and human milk. However, no direct comparative in vitro or in vivo digestion studies between cattle and non-cattle milks, focusing on their curd formation characteristics in the stomach, have been reported to date. There are only a few comparative in vitro digestion studies on cattle and non-cattle milks, focusing on their protein or fat digestion.

Jasińska (131) compared the degrees of hydrolysis by pepsin and trypsin of micellar caseins obtained from cattle, human, goat, and horse skim milk; the peptic hydrolysis rates of the micellar caseins from cattle, human, goat, and horse milks were 23-42 (differed for different breeds of cattle), 80, 65, and 43\%, respectively. The tryptic hydrolysis rates of the micellar caseins from cattle, human, goat, and horse milk were 76-90, 100, 96, and $92 \%$, respectively. The higher susceptibility of human and goat milk was believed to be due to the smaller micellar aggregates and the presence of higher proportions of $\beta$-casein in their micellar structures, when compared with cattle milk (which had higher proportions of $\alpha_{s 1}$-casein).

Recently, Hodgkinson et al. (132) studied the in vitro static gastric digestion of cattle and goat whole milk (at $\mathrm{pH}$ 3.0) and reported that, after both 20 and 60 min of digestion, goat milk caseins were digested faster than cattle milk caseins (based on sodium dodecyl sulfate polyacrylamide gel electrophoresis (SDSPAGE) image analysis), possibly because of the relatively soft or fragile coagulum formed by goat milk. Tagliazucchi et al. (133) also studied the in vitro static gastrointestinal digestion of cattle, goat, sheep, and camel skim milk (as per the INFOGEST protocol) and reported that the extent of free amino groups generated during the gastric digestion was higher for goat, sheep, and camel milk proteins, indicating that the proteins in these non-cattle milks were hydrolyzed faster than cattle milk proteins during the gastric step. However, after the intestinal step, they reported that only the goat milk proteins were hydrolyzed faster than the milk proteins from the other species, all of which had similar hydrolysis rates. Tagliazucchi et al. (134) and Rutella et al. (135) reported similar findings in their previous studies, i.e., that the degree of hydrolysis of goat skim milk proteins during the gastric and intestinal steps was much higher than that of cattle skim milk proteins. The authors stated that the higher degree of hydrolysis of goat milk proteins observed in all studies was probably due to the higher susceptibility of goat milk proteins to pepsin.

Maathuis et al. (136) investigated the comparative protein digestibilities and qualities (based on bioaccessible nitrogen and amino acids) of human milk, cattle-milk-based infant formula, and goat-milk-based infant formula using the tiny-TIM model (a dynamic in vitro infant gastrointestinal model). They found that the protein digestibilities and qualities of all diets were similar; however, the rates of protein digestion were slower during the first 60 min of digestion for the cattle-milk-based formula than for the human milk and the goat-milk-based formula. They hypothesized that the differences in the clotting characteristics of different milks would have led to differences in their gastric emptying, as they found that the curds formed from the cattlemilk-based formula were retained for a longer duration in the gastric compartment of tiny-TIM compared with those from the human milk and the goat-milk-based infant formula. Similarly, Ye et al. (32) investigated the in vitro dynamic gastric digestion of goat- and cattle-milk-based formulas in a mini version of the human gastric simulator (HGS), simulating infant gastric digestion. The authors found that the goat-milk-based infant formula formed smaller protein aggregates in the mini-HGS, leading to faster hydrolysis of its proteins compared with those from the cattle milk formula. Based on the above-mentioned studies it appears that the differences in the structures of the curds formed from milk of different species during gastric digestion may be a key factor that is responsible for their different digestion behaviors.

In contrast, Almaas et al. (137) did not find any differences in the digestion of caseins and $\alpha$-lactalbumin from cattle and goat skim milk (with high and low $\alpha s_{1}$-casein content) after static gastrointestinal digestion using human gastric juice (HGJ) and human duodenal juice (HDJ). They also did not find any differences between goat milk with high and low $\alpha s_{1}$ casein content after digestion with HGJ and HDJ. However, they observed (using SDS-PAGE image analysis) that goat milk $\beta$-lactoglobulin was rapidly digested during both gastric digestion and intestinal digestion, compared with cattle milk $\beta$-lactoglobulin. El-Zahar et al. (138) studied the hydrolysis of isolated $\beta$-lactoglobulin from sheep and cattle milk by porcine pepsin and found that $\beta$-lactoglobulin from sheep milk was hydrolyzed faster because of its slightly different tertiary structure and higher surface hydrophobicity. As $\beta$-lactoglobulin is considered to be one of the major allergens (as it is absent in human milk), the higher degree of hydrolysis by pepsin of the $\beta$-lactoglobulin in goat and sheep milk may be a possible reason that these non-cattle milks are better tolerated by some people than cattle milk.

Vithana et al. (23) studied the comparative in vitro gastrointestinal digestion of raw cattle and deer skim milk. They found that, after gastric digestion, nearly 49 and $27 \%$ of the deer and cattle milk caseins remained undigested (SDS-PAGE image analysis), respectively, whereas, after intestinal digestion, the caseins from both species were completely digested. This, indicated that, during the gastrointestinal digestion, deer milk caseins were digested at a faster rate than cattle milk caseins. We hypothesize that the higher amounts of caseins retained in the gastric phase for deer skim milk may have been due to the higher protein content (as well as casein content) of the deer milk used in their study, indicating that the inherent composition of milk also has a key role to play during gastric digestion. Vithana et al. (23) also found that $\alpha$-lactalbumin was hydrolyzed faster in deer milk than in cattle milk. However, $\beta$-lactoglobulin from both species was found to be resistant to both gastric and duodenal digestion.

In contrast to the above studies, some studies have reported no differences or faster hydrolysis of cattle milk proteins than 
of goat milk proteins. For instance, Inglingstad et al. (139) reported (based on SDS-PAGE image analysis) that 69 and $82 \%$ of the caseins remained undigested after hydrolysis by HGJ of cattle and goat skim milks respectively; however, after further treatment with HDJ, almost all of the caseins from the milk of both species were digested. They found that the $\beta$-lactoglobulin and $\alpha$-lactalbumin from both species were highly resistant to HGJ and that, after hydrolysis with HDJ, $\sim 64 \%$ of the $\beta$-lactoglobulin from both species remained undigested and 91 and $65 \%$ of the $\alpha$-lactalbumin from the cattle and goat skim milk respectively, remained undigested. Mros et al. (140) reported no differences in the protein digestion of cattle, goat, and sheep skim milk following hydrolysis by pepsin and pancreatin.

Similarly, Milan et al. (141) reported that whole goat-protein fortified milk, compared to whole cow-protein fortified milk, was digested and metabolized similarly (despite the differences in their inherent nutrient composition) in young adults (aged 18-28 years). However, they dissolved paracetamol in fortified milk drinks before giving it to the participants for consumption (plasma paracetamol levels were used as a marker for gastric emptying). It has to be noted that depending on the type of paracetamol used, it may have a buffering action during the gastric digestion in the stomach (142) and thus, careful consideration needs to be made while conducting human digestion studies to draw any firm conclusions.

Vaisman et al. (143) investigated the gastric emptying times in humans of camel and cattle milk using a scintigraphic technique and reported that the poor coagulation properties of camel milk (as observed during acid or rennet coagulation) did not provide any comparative advantage over cattle milk in terms of gastric emptying. It should be noted that the soft or fragile curd formed from non-cattle milks (such as camel, goat, horse, and donkey milk) during acid or rennet coagulation provides only an indication of how these non-cattle milks may behave in the human stomach during gastric digestion. The gastric digestion process is a complex and dynamic phenomenon, and in-depth comparative in vitro and in vivo studies on cattle and non-cattle milks that simulate the gastric digestion in humans need to be undertaken, to draw any definite conclusions.

Not only protein composition and (or) casein micelle structure, but also different processing temperature and time combinations may induce differences in the curd structure in the stomach, which may influence the rate of delivery of proteins to the small intestine and their subsequent absorption. For instance, Ye et al. (107) studied the dynamic gastric digestion behavior of raw and heated $\left(90^{\circ} \mathrm{C}\right.$ for $\left.20 \mathrm{~min}\right)$ cattle skim milk using an HGS. The HGS is a dynamic stomach model that is capable of simulating the stomach contraction forces and the flow of gastric fluids that occur in vivo (144). Ye et al. (107) found that raw milk formed a "closely knitted" tight clot, whereas heated milk formed fine and loose protein aggregates (Figure 2), leading to slow hydrolysis of caseins from raw milk, compared with heated milk. This was because, in raw milk, only the caseins were involved in clot formation, whereas, in heated milk, both the caseins and denatured whey proteins were involved in clot formation (145). Heating at $90^{\circ} \mathrm{C}$ for $20 \mathrm{~min}$ would have led to complex formation between fully denatured whey proteins and caseins via sulfhydryl groups and disulfide linkages (Figure 3),
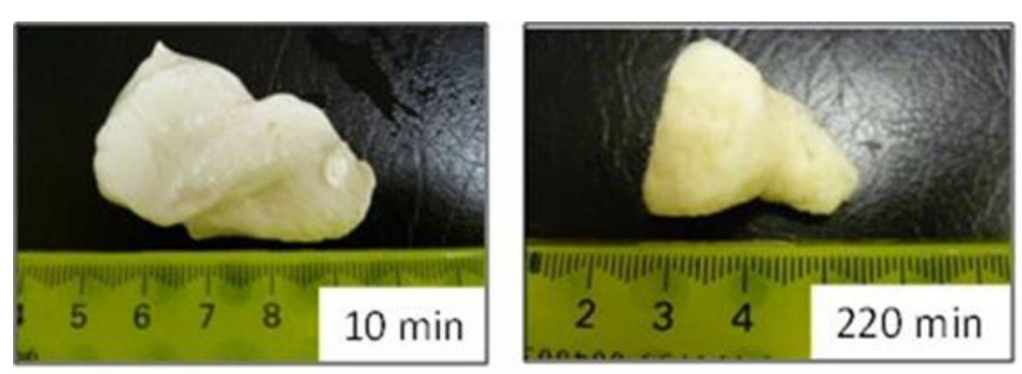

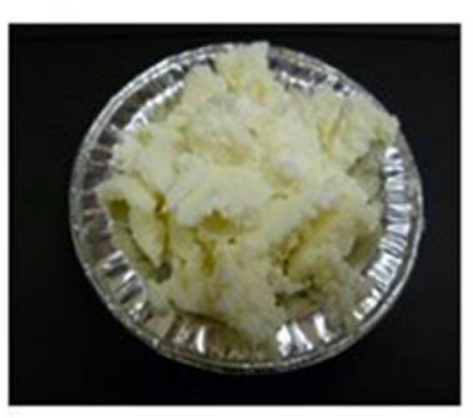

$10 \mathrm{~min}$

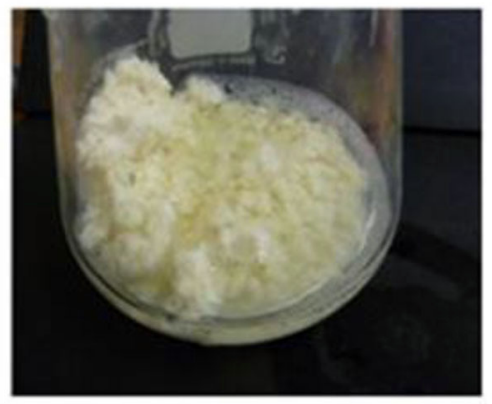

$220 \mathrm{~min}$

FIGURE 2 | Images of clots formed during the gastric digestion of $200 \mathrm{~g}$ of unheated (top row) and heated (bottom row) cattle skim milk at different digestion times. Source: Adapted from Ye et al. (107). 
A
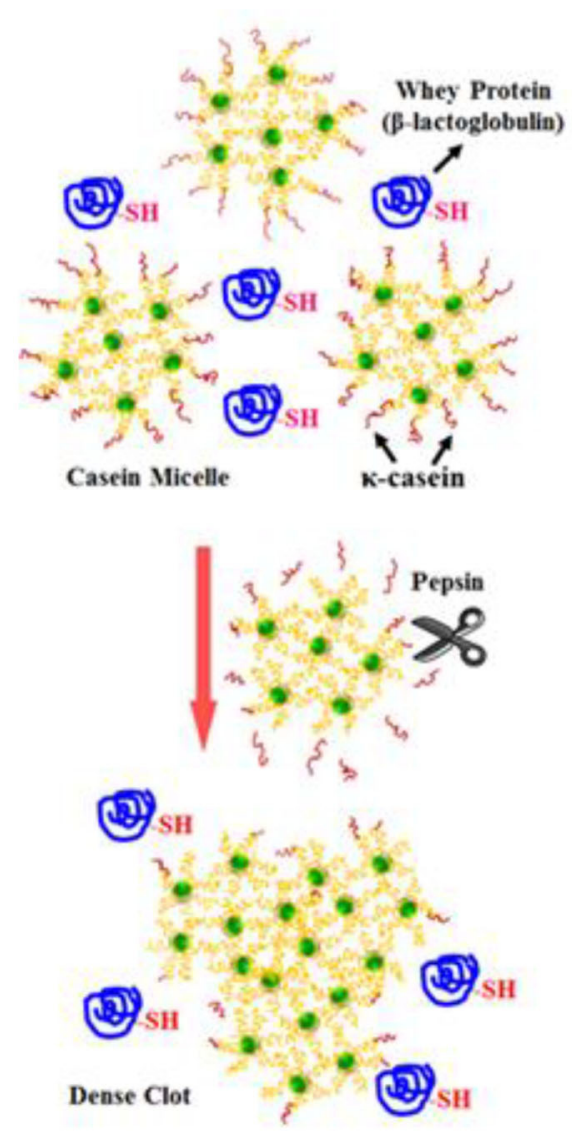

Slow Hydrolysis
B
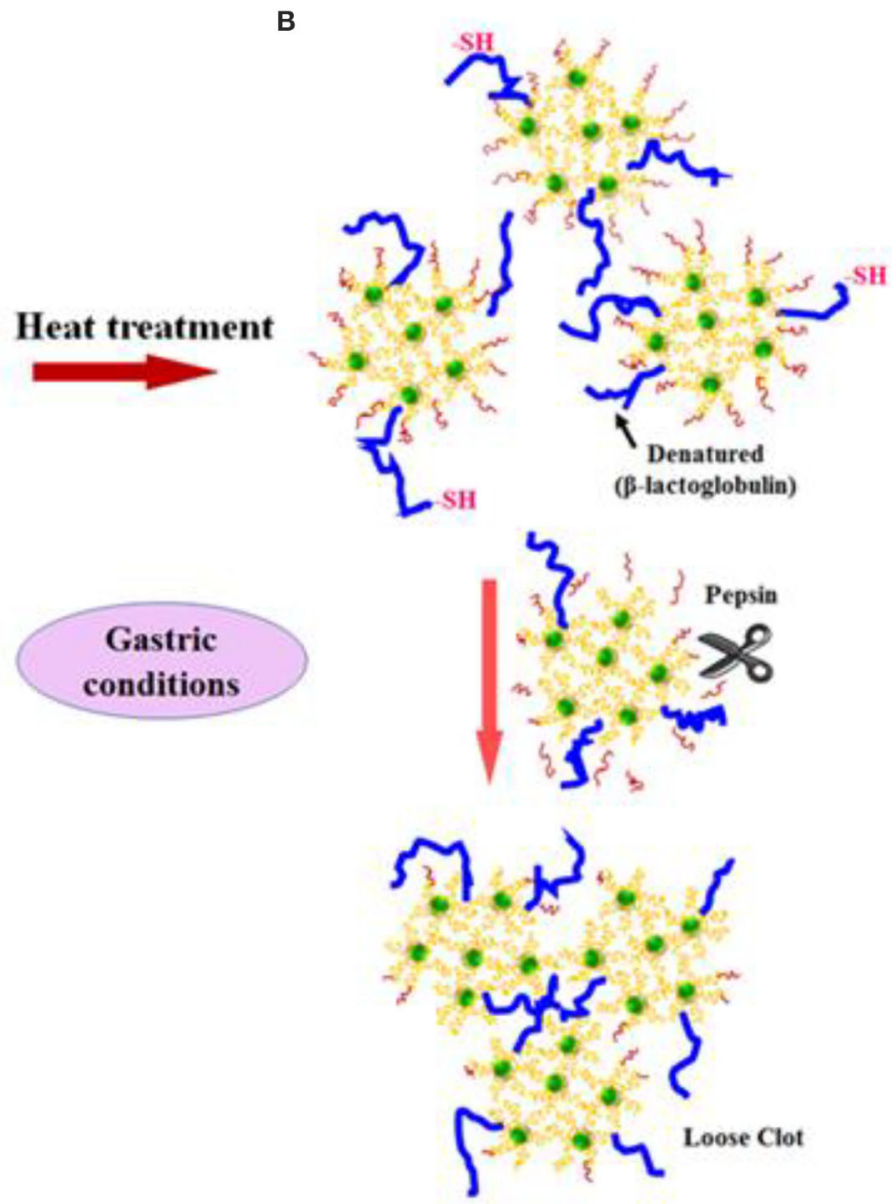

Quick Hydrolysis

FIGURE 3 | Schematic diagram of the possible mechanism of events during the formation of protein curds from (A) raw milk (unheated) and (B) heated milk during gastric digestion. Source: Adapted from Ye et al. (145).

hindering the formation of a firm clot (146, 147). Kaufmann (148) reported that ultrahigh-temperature-treated (UHT) milk led to the formation of soft coagulates in the mini-pigs stomach, leading to higher levels of amino acids and urea in their blood serum compared to that of pasteurized and raw milk, which formed stronger coagulum. Thus, these differences in gastric restructuring induced by heating are expected to be a key possible reason for higher postprandial utilization of dietary nitrogen from defatted UHT milk $\left(140^{\circ} \mathrm{C}\right.$ for $\left.5 \mathrm{~s}\right)$ compared to defatted pasteurized milk ( $72^{\circ} \mathrm{C}$ for $20 \mathrm{~s}$ ) as well as defatted microfiltered milk in humans (149).

Doan (150) published a comprehensive review based on studies on the gastric digestion of processed (boiled, evaporated, or acidified) and raw cattle milk in the early 1900s, and reported that boiled, evaporated, or acidified milk were emptied rapidly from the human stomach because of the finer or softer curd that formed. It was suggested that the modification of raw cattle milk using different processing conditions may be a potential option in the development of dairy-based baby foods or beverages with properties similar to those of human milk.

To date, no studies on the impact of different heating or processing conditions on the digestion behaviors of non-cattle milks have been reported in the literature. It should be noted that the commercial processing or technological conditions needed for non-cattle milks may be different from those needed for cattle milk. In addition, the impact of different processing conditions on the digestion behaviors of non-cattle milks may be different from that on cattle milk because of the differences in their composition and structures.

\section{The Influence of the Protein Network on Fat Digestion-The Whole Milk Matrix}

During the gastric digestion of whole milk, the fat globules are known to be physically entrapped within the protein clot that is formed. Thus, the nature or structure of the protein network formed will influence the rate of release and the digestion of fat 
by gastrointestinal lipases $(145,151-153)$. Previous studies have shown that the nature or structure of the protein network formed is, in turn, dependent on the protein composition (casein-towhey-protein ratio), the protein-to-fat ratio, and the impact of different processing conditions $(99,154)$. For instance, MuletCabero et al. (154) studied the in vitro gastrointestinal digestion of model systems based on different casein-to-whey-protein ratios using a semidynamic gastric model, and reported that the viscosity or firmness of the coagulum formed increased as the casein-to-whey-protein ratio increased in the model protein systems, leading to slower gastric emptying, and slower digestion and absorption of nutrients. They also found that the addition of increasing amounts of fat to the casein-rich protein models produced more fragmented clots with a significant decrease in their firmness. This, indicates that the presence of fat hindered the aggregation of proteins, which may, in turn, influence the digestion rates of nutrients.

Ye et al. (151) studied the gastric digestion of raw (unheated) and heated $\left(90^{\circ} \mathrm{C}\right.$ for $\left.20 \mathrm{~min}\right)$ cattle whole milk and reported that the release of fat globules was dependent on the disintegration characteristics of the protein clot and that the release of fat globules was higher from the finer aggregates of protein clots formed from the heated whole milk than from the firm clots formed from the raw whole milk (Figure 4). Similarly, Ye et al. (145) studied the comparative in vitro and in vivo (in rats) gastric digestions of raw (nonhomogenized), pasteurized (homogenized), and UHT (homogenized) cattle whole milk, and reported that the UHT milk had faster rates of protein hydrolysis as well as release of fat globules during gastric digestion, compared with the raw and pasteurized milk; the differences were attributed to the smaller or fragmented protein aggregates formed from the UHT milk proteins in comparison with the aggregates from the other milks.

In another gastric digestion study, Ye et al. (152) reported that the release of fat globules was relatively higher in homogenized

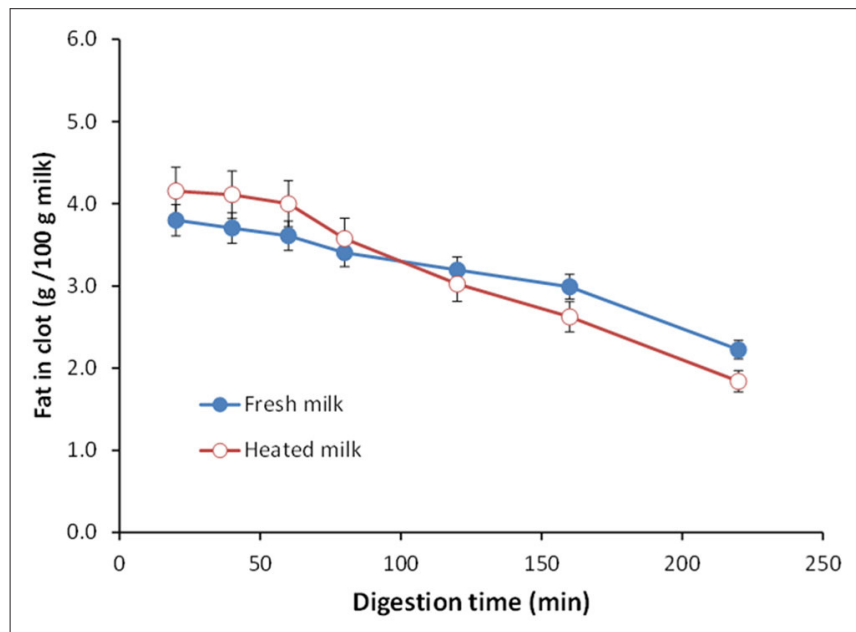

FIGURE 4 | Changes in the fat content ( $\mathrm{g} / 100 \mathrm{~g}$ milk) in clots obtained from $(\bullet)$ unheated (raw) and (०) heated cattle whole milk during gastric digestion. Source: Adapted from Ye et al. (151). milk (20/5 $\mathrm{MPa}$ (primary/secondary pressure), $20^{\circ} \mathrm{C}$ ) as well as heated, homogenized milk $\left(20 / 5 \mathrm{MPa}, 20^{\circ} \mathrm{C}+90^{\circ} \mathrm{C}\right.$ for $\left.20 \mathrm{~min}\right)$ because of the fine and crumbled structure of the coagulum formed in these milks compared with the firm coagulum formed from raw cattle whole milk (Figure 5). Similar results have been reported by Mulet-Cabero et al. (153) for processed cattle whole milks.

The coalescence of fat globules entrapped within the protein network as well as those present in the liquid phase of the gastric chyme has also been reported in the above-mentioned studies $(145,152,153)$, which is expected to be due to the hydrolysis of the proteins present at the surface of the milk fat globule (present naturally in the MFGM or adsorbed proteins because of processing treatments), leading to destabilization of the fat globules and coalescence.

As the milk from different species are known to vary in fat content, protein-to-fat ratio, fat globule size, and structure, there may be differences in the consistency of the coagulum formed from milk of different species during gastric digestion, which may impact their overall digestion behavior differently.

\section{Gastrointestinal Digestion of Fat}

Little information is available on the gastric digestion of milk fat, irrespective of species. Lipolysis during the gastric phase was previously considered to be of less relevance during the overall digestion process as gastric lipolysis accounts for only $10-25 \%$ of the overall lipid digestion in adults (155). Therefore, most of the studies reported in the literature on fat digestion have focused mainly on intestinal digestion. However, it is now widely suggested that gastric lipases should be incorporated in in vitro digestion studies as their preliminary role may facilitate further breakdown of lipids by intestinal lipases (155). Also, in contrast to adults, gastric lipases play a significant role in infants because of their high postprandial gastric $\mathrm{pH}$ (156).

It is hypothesized that, the smaller the fat globule size, the higher will be the fat digestibility, because the higher surface area of smaller fat globules will help in rapid digestion via gastrointestinal lipases $(13,18,19,157)$. Meena et al. (158) investigated the digestion of milk fat by pancreatic lipase in standardized raw cattle, buffalo, camel, and goat whole milk. The authors found that the amount of free fatty acids released followed the order: goat $\sim$ camel $>$ cattle $>$ buffalo. The higher digestibility of goat and camel whole milk was believed to be due to the small size of their fat globules, as the fat globule sizes of the different milks were in the order: buffalo $(3.9-7.7 \mu \mathrm{m})>$ cattle $(1.6-4.9 \mu \mathrm{m})>$ goat $(1.1-3.9 \mu \mathrm{m}) \sim$ camel $(1.1-2.1 \mu \mathrm{m})$. In addition to the fat globule size, the outer surface of the fat globule and its structure (i.e., the fat globule interface) have a crucial role to play in the digestion of fats. For example, the presence of adsorbed proteins (caused by processing such as heating and homogenization) at the interface of fat globules may result in providing easy access of lipases to the TAG core of the fat globules and thus in influencing the digestion of milk fat (157).

Some studies have also shown the influence of differences in the milk fat composition among different milks on their digestibility. For instance, Alférez et al. (159) studied the fat digestibility and metabolism in feces samples of male albino rats 


\section{Fresh whole milk}
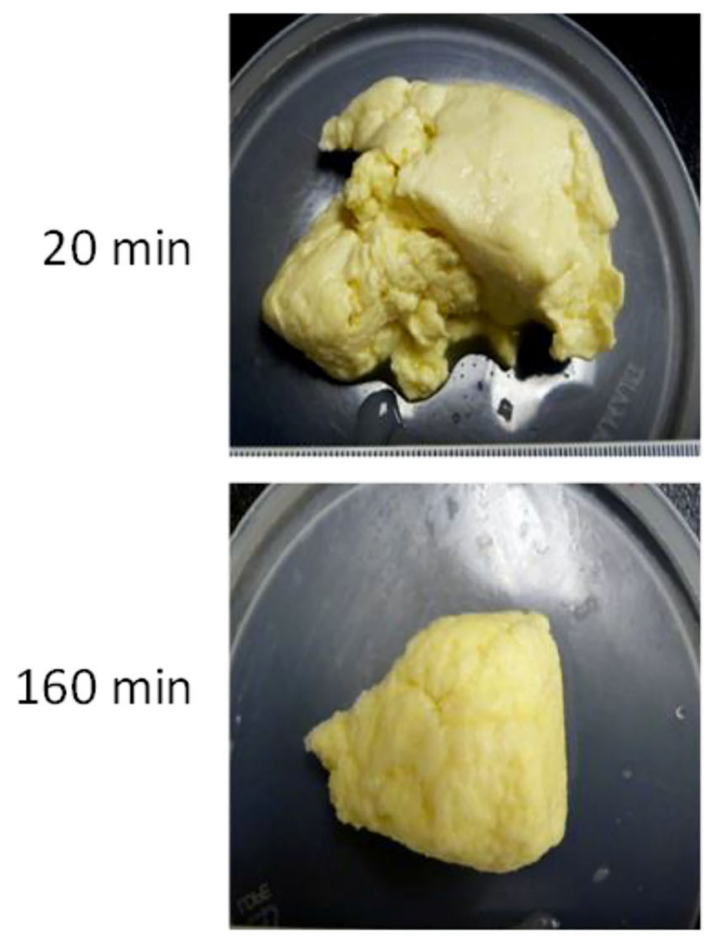

Homogenized milk
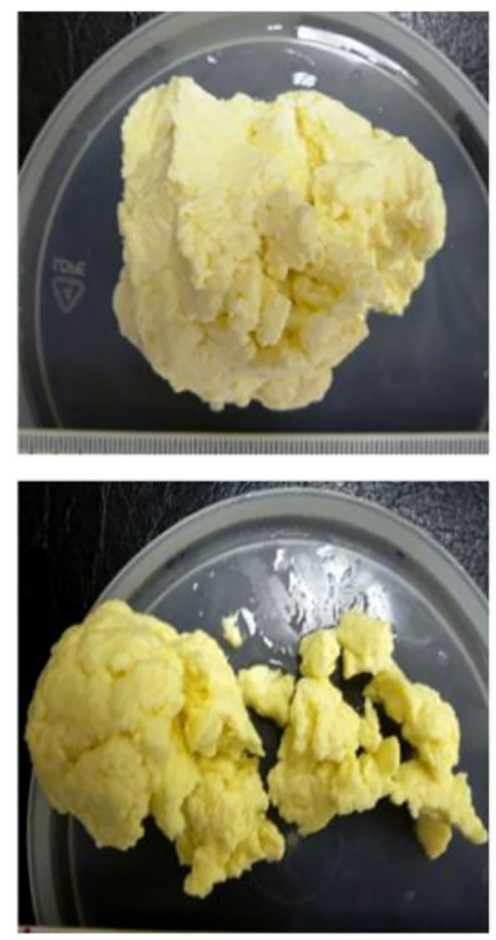

Heated $\left(90^{\circ} \mathrm{C}, 20 \mathrm{~min}\right)$ Homogenized milk
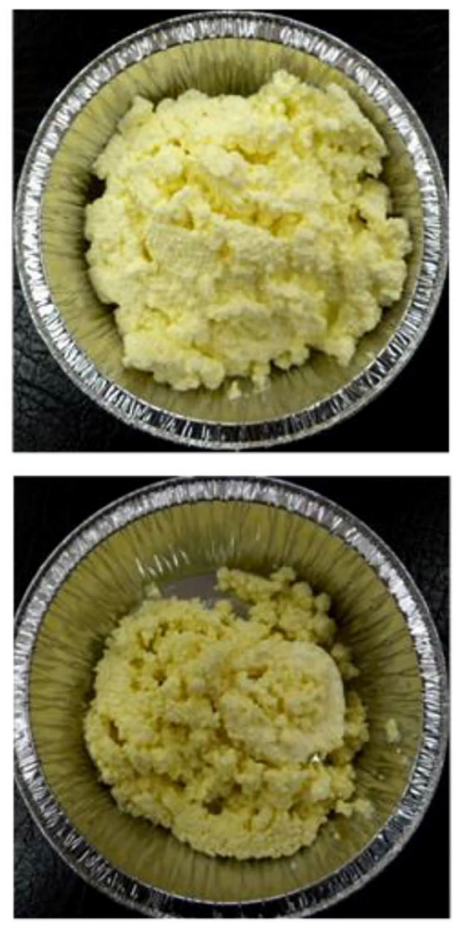

FIGURE 5 | Images of clots formed during the gastric digestion of raw (unheated), homogenized, and heated homogenized cattle whole milk during 20 and 160 min of gastric digestion. Source: Adapted from Ye et al. (152).

that were fed diets containing lyophilized goat and cattle whole milk. They found that, compared with the rats on the cattlemilk-based diet, the digestive utilization of fat was higher, and the levels of cholesterol were lower, in the rats on the goat-milkbased diet. The authors believed that the differences may have been due to the greater amounts of medium chain TAGs and the smaller fat globule sizes of the goat milk fat compared with the cattle milk fat used in their study. Similarly, Teng et al. (160) studied the in vitro gastric digestion of raw (non-homogenized) and homogenized cattle and sheep milk, and reported that the TAGs from both raw and homogenized sheep milk were digested by rabbit gastric lipases more rapidly than those from cattle milk; this was due to the presence of higher levels of medium chain fatty acids at the sn-1 or sn-3 position of the TAG structure in sheep milk compared with cattle milk, emphasizing that the structural characteristics of TAGs have an important role to play in their gastric digestion.

Overall, the digestibilities of the protein and fat in milk are likely to be functions of the unique compositions, protein profiles, fat compositions, casein micelle and fat globule structures, interfacial properties, mineral distributions, and physicochemical properties, all of which are likely to be affected to different degrees by the processing conditions, depending on the animal species. Although there are very few studies on the impact of the processing conditions and the milk composition of non-cattle milks in the literature, the principles of cattle milk protein coagulation and its impact on fat digestion are expected to also be applicable to non-cattle milks. However, as cattle and non-cattle milks vary in protein composition (proportion of different proteins) as well as protein-to-fat ratio, it is likely that there will be differences in the structure and consistency of the protein curd (or clot) formed from different milks, which may lead to further differences in the release of fat globules from the clot matrix of different milks. It should also be noted that the gastric and intestinal digestion conditions of infants (as well as the elderly) are different from those of adults in terms of acid secretions and enzyme (proteases and lipases) activities $(155,156,161)$. Thus, relevant dynamic in vitro models need to be used to study the digestion of milks in different age groups, and in vitro results need to be ultimately corroborated based on in vivo observations.

\section{CONCLUSIONS AND RECOMMENDATIONS FOR FUTURE RESEARCH}

As non-cattle milk and milk products are highly regarded as a potential source of human nutrition, they can be utilized 
to develop specialized dairy products for people in all age groups. Non-cattle milks are of great interest to people as well as industries, because of their perceived better nutritional properties compared with cattle milk. However, most of these presumptions are based on anecdotal reports and only little scientific research has been conducted to understand the nutritional and physicochemical properties of non-cattle milks. One widely perceived notion is the formation of soft curds in the human stomach for some non-cattle milks (such as goat, camel, horse, and donkey milk). Because of this, these milks are considered to be better digested and tolerated by people of different age groups. However, to date, no direct scientific studies have been reported and there is a knowledge gap. As cattle and non-cattle milks vary in composition and structure of the casein micelles and fat globules, they are likely to behave differently in the gastrointestinal tract, possibly affecting the kinetics of digestion and the bioavailability of nutrients. Because of differences in milk composition and the structure of the casein micelles (or fat globules), there may be differences in the curds formed by the milk of each species in the stomach, which may further affect the delivery rates of macronutrients further down the gastrointestinal tract. Furthermore, different commercial processing conditions such as pasteurization or UHT (or other heat treatments) may influence the digestion behaviors of non-cattle milks differently. Thus, in-depth scientific studies need to be conducted to understand the impact of compositional as well as structural differences in milk from different species (in their natural form as well as processed forms) on their dynamic digestion behaviors, especially focusing on their differences in

\section{REFERENCES}

1. Dunne J, Evershed RP, Salque M, Cramp L, Bruni S, Ryan K, et al. First dairying in green Saharan Africa in the fifth millennium BC. Nature. (2012) 486:390-94. doi: 10.1038/nature11186

2. Evershed RP, Payne S, Sherratt AG, Copley MS, Coolidge J, UremKotsu D, et al. Earliest date for milk use in the near East and southeastern Europe linked to cattle herding. Nature. (2008) 455:528-31. doi: $10.1038 /$ nature 07180

3. Faye B, Konuspayeva G. The sustainability challenge to the dairy sector - the growing importance of non-cattle milk production worldwide. Int Dairy J. (2012) 24:50-56. doi: 10.1016/j.idairyj.2011. 12.011

4. Park YW, Haenlein GFW. Overview of milk of non-bovine mammals. In: Park YW, Haenlein GFW, editors. Handbook of Milk of Non-Bovine Mammals. Oxford: Blackwell Publishing Professional (2006). p. 3-9. doi: 10.1002/9780470999738.ch1

5. Verduci E, D’Elios S, Cerrato L, Comberiati P, Calvani M, Palazzo S, et al. Cow's milk substitutes for children: nutritional aspects of milk from different mammalian species, special formula and plant-based beverages. Nutrients. (2019) 11:1739. doi: 10.3390/nu11081739

6. Ribeiro AC, Ribeiro SDA. Specialty products made from goat milk. Small Rumin. Res. (2010) 89:225-33. doi: 10.1016/j.smallrumres.2009. 12.048

7. Haenlein GFW. Goat milk in human nutrition. Small Rumin Res. (2004) 51:155-63. doi: 10.1016/j.smallrumres.2003.08.010

8. Alichanidis E, Moatsou G, Polychroniadou A. Composition properties of non-cow milk products. In: Tsakalidou E, Papadimitriou K, editors. NonBovine Milk Milk Products. New York, NY: Academic Press (2016). p. 81-116. doi: 10.1016/B978-0-12-803361-6.00005-3 curd formation as well as their disintegration properties in the stomach. Such studies will often involve in vitro digestion models, which where possible should be dynamic and sophisticated enough to at least include the effects of key variables known to influence food digestion. Further, the physiological relevance of such phenomena needs to be investigated in animal and human studies focusing on different age groups or people in need of targeted personalized nutrition (such as infants, the elderly, athletes or malnourished people).

\section{AUTHOR CONTRIBUTIONS}

DR prepared the original draft and edited the manuscript. HS critiqued and edited the original draft of the manuscript. AY and PM critically reviewed the manuscript. All authors listed have made a substantial, direct, and intellectual contribution to the conception and design of the manuscript and read and approved the final manuscript for publication.

\section{FUNDING}

This study was supported by Tertiary Education CommissionCenter of Research Excellence (CoRE) funding, New Zealand.

\section{ACKNOWLEDGMENTS}

The authors would like to thank the Riddet Institute (Massey University) for a $\mathrm{PhD}$ scholarship for DR.

9. Park YW, Guo M. Goat milk products: types of products, manufacturing technology, chemical composition, and marketing. In: Park YW, Haenlein GFW, editors. Handbook of Milk of Non-Bovine Mammals. Oxford: Blackwell Publishing, Ltd (2006). p. 59-106. doi: 10.1002/9780470999738.ch4

10. Burgess K. Key requirements for milk quality and safety: a processor's perspective. In: Griffiths MW, editor. Improving the Safety and Quality of Milk-Volume 1. Cambridge, UK: Woodhead Publishing Ltd (2010). p. 64-84. doi: 10.1533/9781845699420.1.64

11. Bencini R, Atzori AS, Nudda A, Battacone G, Pulina G. Improving the quality and safety of sheep milk. In: Griffiths MW, editor. Improving the Safety and Quality of Milk-Volume 2. Cambridge, UK: Woodhead Publishing Ltd (2010). p. 347-401. doi: 10.1533/9781845699437.3.347

12. Regenstein JM, Chaudry MM, Regenstein CE. The kosher and halal food laws. Compr Rev Food Sci Food Saf. (2003) 2:111-27. doi: 10.1111/j.1541-4337.2003.tb00018.x

13. Crowley SV, Kelly AL, Lucey JA, O'Mahony JA. Potential applications of nonbovine mammalian milk in infant nutrition. In: Park YW, Haenlein GFW, Wendorff WL, editors. Handbook of Milk of Non-Bovine Mammals. Oxford: John Wiley \& Sons, Ltd (2017). p. 625-54. doi: 10.1002/9781119110316.ch13

14. Potočnik K, Gantner V, Kuterovac K, Cividini A. Mare’s milk: composition and protein fraction in comparison with different milk species. Mljekarstvo. (2011) 61:107-13. Available online at: https://hrcak.srce.hr/69078

15. Balthazar CF, Pimentel TC, Ferrão LL, Almada CN, Santillo A, Albenzio $\mathrm{M}$, et al. Sheep milk: physicochemical characteristics and relevance for functional food development. Compr Rev Food Sci Food Saf. (2017) 16:24762. doi: 10.1111/1541-4337.12250

16. Ranadheera CS, Evans CA, Baines SK, Balthazar CF, Cruz AG, Esmerino EA, et al. Probiotics in goat milk products: delivery capacity and ability to improve sensory attributes. Compr Rev Food Sci Food Saf. (2019) 18:867-82. doi: $10.1111 / 1541-4337.12447$ 
17. Barlowska J, Szwajkowska M, Litwinczuk Z, Krol J. Nutritional value and technological suitability of milk from various animal species used for dairy production. Compr Rev Food Sci Food Saf. (2011) 10:291-302. doi: 10.1111/j.1541-4337.2011.00163.x

18. Gantner V, Mijic P, Baban M, Skrtic Z, Turalija A. The overall and fat composition of milk of various species. Mljekarstvo. (2015) 65:223-31. doi: $10.15567 / \mathrm{mljekarstvo.2015.0401}$

19. Claeys WL, Verraes C, Cardoen S, De Block J, Huyghebaert A, Raes K, et al. Consumption of raw or heated milk from different species: an evaluation of the nutritional and potential health benefits. Food Control. (2014) 42:188201. doi: 10.1016/j.foodcont.2014.01.045

20. Arman P, Kay R, Goodall E, Sharman G. The composition and yield of milk from captive red deer (Cervus elaphus L.). J Reprod Fertil. (1974) 37:67-84. doi: 10.1530/jrf.0.0370067

21. Krzywiński A, Krzywińska K, Kisza J, Roskosz A, Kruk A. Milk composition, lactation and the artificial rearing of red deer. Acta Theriol. (1980) 25:341-7. doi: 10.4098/AT.arch.80-31

22. Landete-Castillejos T, Garcia A, Molina P, Vergara H, Garde J, Gallego L. Milk production and composition in captive Iberian red deer (Cervus elaphus hispanicus): effect of birth date. J Anim Sci. (2000) 78:2771-7. doi: $10.2527 / 2000.78112771 \mathrm{x}$

23. Vithana NLO, Mason S, Bekhit A, Morton J. In vitro digestion of red deer (Cervus elaphus) and cow (Bos taurus) milk. Int Food Res J. (2012) 19:1367-74. Available online at: http://www.ifrj.upm.edu.my/19 \%20(04)\%202012/10\%20IFRJ\%2019\%20(04)\%202012\%20Nelum\%20(074). pdf

24. Wang Y, Bekhit AEDA, Morton JD, Mason S. Nutritional value of deer milk. In: Watson RR, Collier RJ, Preedy V, editors. Nutrients in Dairy and their Implications for Health and Disease. 1st Edn. New York, NY: Academic Press (2017). p. 363-75. doi: 10.1016/B978-0-12-809762-5.00028-0

25. Martinez-Ferez A, Rudloff S, Guadix A, Henkel CA, Pohlentz G, Boza JJ, et al. Goats' milk as a natural source of lactose-derived oligosaccharides: isolation by membrane technology. Int Dairy J. (2006) 16:173-81. doi: 10.1016/j.idairyj.2005.02.003

26. Li S, Ye A, Singh, H. Seasonal variations in composition, properties, and heat-induced changes in bovine milk in a seasonal calving system. J Dairy Sci. (2019) 102:7747-59. doi: 10.3168/jds.201916685

27. Oliveira DL, Wilbey RA, Grandison AS, Duarte LC, Roseiro LB. Separation of oligosaccharides from caprine milk whey, prior to prebiotic evaluation. Int Dairy J. (2012) 24:102-6. doi: 10.1016/j.idairyj.2011. 12.012

28. Oliveira DL, Wilbey RA, Grandison AS, Roseiro LB. Milk oligosaccharides: a review. Int J Dairy Technol. (2015) 68:305-21. doi: 10.1111/1471-0307.12209

29. Roy D, Ye A, Moughan PJ, Singh, H. Gelation of milks of different species (dairy cattle, goat, sheep, red deer, and water buffalo) using glucono- $\delta$-lactone and pepsin. J Dairy Sci. (2020) 103:5844-62. doi: 10.3168/jds.2019-17571

30. Kappeler S. Compositional and structural analysis of camel milk proteins with emphasis on protective proteins. (thesis). Zurich, ETH Zurich (1998)

31. Tari NR, Fan MZ, Archbold T, Kristo E, Guri A, Arranz E, et al. Effect of milk protein composition of a model infant formula on the physicochemical properties of in vivo gastric digestates. J Dairy Sci. (2018) 101:2851-61. doi: $10.3168 /$ jds.2017-13245

32. Ye A, Cui J, Carpenter E, Prosser C, Singh H. Dynamic in vitro gastric digestion of infant formulae made with goat milk and cow milk: influence of protein composition. Int Dairy J. (2019) 97:76-85. doi: 10.1016/j.idairyj.2019.06.002

33. Selo I, Clement G, Bernard H, Chatel J-M, Creminon C, Peltre $\mathrm{G}$, et al. Allergy to bovine $\beta$-lactoglobulin: specificity of human IgE to tryptic peptides. Clin Exp Allergy. (1999) 29:1055-63. doi: 10.1046/j.1365-2222.1999.00612.x

34. Ereifej KI, Alu'datt MH, AlKhalidy HA, Alli I, Rababah T. Comparison and characterisation of fat and protein composition for camel milk from eight jordanian locations. Food Chem. (2011) 127:282-9. doi: 10.1016/j.foodchem.2010.12.112

35. El-Hatmi H, Jrad Z, Salhi I, Aguibi A, Nadri A, Khorchani T. Comparison of composition and whey protein fractions of human, camel, donkey, goat and cow milk. Mljekarstvo. (2015) 65:159-67. doi: $10.15567 / \mathrm{mljekarstvo.2015.0302}$

36. Farah Z. Effect of heat treatment on whey proteins of camel milk. Milchwissenschaft. (1986) 41:763-65.

37. Beg OU, von Bahr-Lindström H, Zaidi ZH, Jörnvall H. Characterization of a heterogeneous camel milk whey non-casein protein. FEBS Lett. (1987) 216:270-74. doi: 10.1016/0014-5793(87)80704-4

38. Beg OU, von Bahr-Lindström H, Zaidi ZH, Jörnvall H. A small camelmilk protein rich in cysteine/half-cystine. Biosci Rep. (1984) 4:1065-70. doi: 10.1007/BF01116700

39. Park YW, Haenlein GFW. Other minor species milk (Reindeer, Caribou, Musk Ox, Llama, Alpaca, Moose, Elk, and Others). In: Park YW, Haenlein GFW, editors. Milk and Dairy Products in Human Nutrition. Oxford: WileyBlackwell Publishers (2013). p. 644-58. doi: 10.1002/9781118534168.ch30

40. De Kruif CG, Huppertz T, Urban VS, Petukhov AV. Casein micelles and their internal structure. Adv Colloid Interface Sci. (2012) 171:36-52. doi: 10.1016/j.cis.2012.01.002

41. Ingham B, Smialowska A, Kirby N, Wang C, Carr A. A structural comparison of casein micelles in cow, goat and sheep milk using X-ray scattering. Soft Matter. (2018) 14:3336-43. doi: 10.1039/C8SM00458G

42. Nguyen HTH, Afsar S, Day L. Differences in the microstructure and rheological properties of low-fat yoghurts from goat, sheep and cow milk. Food Res Int. (2018) 108:423-9. doi: 10.1016/j.foodres.2018.03.040

43. Pierre A, Michel F, Le Graët Y, Zahoute L. Casein micelle size in relation with casein composition and $\alpha \mathrm{s} 1, \alpha \mathrm{s} 2, \beta$ and $\kappa$ casein contents in goat milk. Lait. (1998) 78:591-605. doi: 10.1051/lait:1998653

44. Pierre A, Michel F, Le Graet, Y. Variation in size of goat milk casein micelles related to casein genotype. Lait. (1995) 75:489-502. doi: 10.1051/lait:1995638

45. Dalgleish DG. The basis of structure in dairy-based foods: casein micelles and their properties. In: Boland M, Golding M, Singh H, editors. Food Structures, Digestion and Health. Amsterdam: Elsevier (2014). p. 83-105. doi: 10.1016/B978-0-12-404610-8.00003-7

46. Wang $\mathrm{P}$, Liu H, Wen $\mathrm{P}$, Zhang H, Guo H, Ren F. The composition, size and hydration of yak casein micelles. Int Dairy J. (2013) 31:107-10. doi: 10.1016/j.idairyj.2013.02.007

47. Dewan RK, Bloomfield VA, Chudgar A, Morr CV. Viscosity and voluminosity of bovine milk casein micelles. J Dairy Sci. (1973) 56:699-705. doi: 10.3168/jds.S0022-0302(73)85236-1

48. Pellegrini O, Remeuf F, Rivemale M. Évolution des caractéristiques physicochimiques et des paramètres de coagulation du lait de brebis collecté dans la région de Roquefort. Lait. (1994) 74:425-42. doi: 10.1051/lait:1994635

49. Remeuf F, Lenoir J, Duby C, Letilly M-T, Normand A. Etude des relations entre les caractéristiques physico-chimiques des laits de chèvre et leur aptitude à la coagulation par la présure. Lait. (1989) 69:499-518. doi: 10.1051/lait:1989634

50. Ahmad S, Gaucher I, Rousseau F, Beaucher E, Piot M, Grongnet JF, et al. Effects of acidification on physico-chemical characteristics of buffalo milk: a comparison with cow's milk. Food Chem. (2008) 106:11-17. doi: 10.1016/j.foodchem.2007.04.021

51. Luo J, Jian S, Wang P, Ren F, Wang F, Chen S, et al. Thermal instability and characteristics of donkey casein micelles. Food Res Int. (2019) 119:436-43. doi: 10.1016/j.foodres.2019.02.023

52. Beaucher E, Nogueira N, Camier B, Jardin J, Briard-Bion V, Musaad A, et al. Physico-chemical characteristics of fresh and corresponding pasteurized camel milks from intensive dairy farm in Saudi Arabia: 479. In: JAM 2013, ADSA-ASAS. Indianapolis, IN (2013).

53. Sood SM, Gaind DK, Dewan, R.K. Correlation between micelle salvation and calcium content. N Zeal J Dairy Sci. Technol. (1979) 14:32-44.

54. Remeuf F, Lenoir J. Relationship between the physico-chemical characteristics of goat's milk and its rennetability. Bull Fédér Int Lait. (1986) 202:68-72.

55. Park YW. Rheological characteristics of goat and sheep milk. Small Rumin Res. (2007) 68:73-87. doi: 10.1016/j.smallrumres.2006.09.015

56. Park YW, Juarez M, Ramos M, Haenlein GFW. Physico-chemical characteristics of goat and sheep milk. Small Rumin Res. (2007) 68:88-113. doi: 10.1016/j.smallrumres.2006.09.013

57. Ceballos LS, Morales ER, de la Torre Adarve G, Castro JD, Martínez LP, Sampelayo MRS. Composition of goat and cow milk produced under similar 
conditions and analyzed by identical methodology. J Food Compost Anal. (2009) 22:322-9. doi: 10.1016/j.jfca.2008.10.020

58. Ruiz-Sala P, Hierro M, Martinez-Castro I, Santa-Maria G. Triglyceride composition of ewe, cow, and goat milk fat. J Am Oil Chem Soc. (1996) 73:283-93. doi: 10.1007/BF02523421

59. Jenness R. Composition and characteristics of goat milk: review 1968-1979. J Dairy Sci. (1980) 63:1605-30. doi: 10.3168/jds.S0022-0302(80)83125-0

60. Abd El-Salam MH, El-Shibiny S. A comprehensive review on the composition and properties of buffalo milk. Dairy Sci Technol. (2011) 91:663. doi: 10.1007/s13594-011-0029-2

61. Kula JT, Tegegne D. Chemical composition and medicinal values of camel milk. Int J Res Stud Biosci. (2016) 4:13-25.

62. Park YW. Goat milk - chemistry and nutrition. In: Park YW, Haenlein GFW, editors. Handbook of Milk of Non-Bovine Mammals. Oxford: Blackwell Publishing Professional (2008). p. 34-58. doi: 10.1002/9780470999738.ch3

63. Jandal J. Comparative aspects of goat and sheep milk. Small Rumin Res. (1996) 22:177-85. doi: 10.1016/S0921-4488(96)00880-2

64. German JB, Dillard CJ. Composition, structure and absorption of milk lipids: a source of energy, fat-soluble nutrients and bioactive molecules. Crit Rev Food Sci Nutr. (2006) 46:57-92. doi: 10.1080/10408690590957098

65. Stroebinger N. The effect of dietary calcium and other nutritionally relevant divalent cations on fatty acid-soap formation. (thesis). Manawatu: Massey University, Manawatu, New Zealand (2016).

66. Innis SM. Dietary triacylglycerol structure and its role in infant nutrition. Adv Nutr. (2011) 2:275-83. doi: 10.3945/an.111.000448

67. Singh H. The milk fat globule membrane-a biophysical system for food applications. Curr Opin Colloid Interface Sci. (2006) 11:154-63. doi: 10.1016/j.cocis.2005.11.002

68. Lopez C, Cauty C, Guyomarc'h F. Unraveling the complexity of milk fat globules to tailor bioinspired emulsions providing health benefits: the key role played by the biological membrane. Eur J Lipid Sci Technol. (2019) 121:1800201. doi: 10.1002/ejlt.201800201

69. Lopez C, Madec M-N, Jimenez-Flores R. Lipid rafts in the bovine milk fat globule membrane revealed by the lateral segregation of phospholipids and heterogeneous distribution of glycoproteins. Food Chem. (2010) 120:22-33. doi: 10.1016/j.foodchem.2009.09.065

70. Nguyen HTH, Ong L, Hoque A, Kentish S, Williamson N, Ang C-S, et al. A proteomic characterization shows differences in the milk fat globule membrane of buffalo and bovine milk. Food Biosci. (2017) 19:7-16. doi: 10.1016/j.fbio.2017.05.004

71. Jenkins JA, Breiteneder H, Mills EN. Evolutionary distance from human homologs reflects allergenicity of animal food proteins. J Allergy Clin Immunol. (2007) 120:1399-405. doi: 10.1016/j.jaci.2007.08.019

72. El-Agamy EI. The challenge of cow milk protein allergy. Small Rumin Res. (2007) 68:64-72. doi: 10.1016/j.smallrumres.2006.09.016

73. Natale M, Bisson C, Monti G, Peltran A, Perono Garoffo L, Valentini $\mathrm{S}$, et al. Cow's milk allergens identification by two-dimensional immunoblotting and mass spectrometry. Mol Nutr Food Res. (2004) 48:363-9. doi: 10.1002/mnfr.200400011

74. Hinz K, O'Connor PM, Huppertz T, Ross RP, Kelly AL. Comparison of the principal proteins in bovine, caprine, buffalo, equine and camel milk. J Dairy Res. (2012) 79:185-91. doi: 10.1017/S0022029912000015

75. Businco L, Giampietro PG, Lucenti P, Lucaroni F, Pini C, Di Felice G, et al. Allergenicity of mare's milk in children with cow's milk allergy. J Allergy Clin. Immunol. (2000) 105:1031-4. doi: 10.1067/mai.2000.106377

76. Tesse R, Paglialunga C, Braccio S, Armenio L. Adequacy and tolerance to ass's milk in an Italian cohort of children with cow's milk allergy. Ital J Pediatr. (2009) 35:19. doi: 10.1186/1824-7288-35-19

77. Monti G, Bertino E, Muratore MC, Coscia A, Cresi F, Silvestro L, et al. Efficacy of donkey's milk in treating highly problematic cow's milk allergic children: an in vivo and in vitro study. Pediatr Allergy Immunol. (2007) 18:258-64. doi: 10.1111/j.1399-3038.2007.00521.x

78. Ehlayel MS, Hazeima KA, Al-Mesaifri F, Bener A. Camel milk: an alternative for cow's milk allergy in children. Allergy Asthma Proc. (2011) 32:255-8. doi: 10.2500/aap.2011.32.3429

79. El-Agamy EI, Nawar M, Shamsia SM, Awad S, Haenlein GF. Are camel milk proteins convenient to the nutrition of cow milk allergic children? Small Rumin Res. (2009) 82:1-6. doi: 10.1016/j.smallrumres.2008.12.016
80. Sheehan WJ, Phipatanakul W. Tolerance to water buffalo milk in a child with cow milk allergy. Ann Allergy Asthma Immunol. (2009) 102:349. doi: 10.1016/S1081-1206(10)60342-0

81. Restani P, Beretta B, Fiocchi A, Ballabio C, Galli CL. Cross-reactivity between mammalian proteins. Ann Allergy Asthma Immunol. (2002) 89:1115. doi: 10.1016/S1081-1206(10)62116-3

82. Katz Y, Goldberg MR, Zadik-Mnuhin G, Leshno M, Heyman E. Crosssensitization between milk proteins: reactivity to a "kosher" epitope? Israel Med Assoc J. (2008) 10:85-8. Available online at: https://www.ima.org.il/ MedicineIMAJ/viewarticle.asp $x$ ?year $=2008 \&$ month $=01$ \&page $=85$

83. Restani P, Gaiaschi A, Plebani A, Beretta B, Cavagni G, Fiocchi A, et al. Cross-reactivity between milk proteins from different animal species. Clin Exp Allergy. (1999) 29:997-1004. doi: 10.1046/j.1365-2222.1999.00563.x

84. Infante PD, Tormo CR, Conde ZM. Use of goat's milk in patients with cow's milk allergy. An Pediatr. (2003) 9:138-42. doi: 10.1016/s1695-4033(03)78737-2

85. Bellioni-Businco B, Paganelli R, Lucenti P, Giampietro PG, Perbornc H, Businco L. Allergenicity of goat's milk in children with cow's milk allergy. J Allergy Clin Immunol. (1999) 103:1191-4. doi: 10.1016/S0091-6749(99)70198-3

86. Robinson F. Goats milk - a suitable hypoallergenic alternative? Br Food J. (2001) 103:198-208. doi: 10.1108/00070700110386746

87. Spuergin P, Walter M, Schiltz E, Deichmann K, Forster J, Mueller H. Allergenicity of $\alpha$-caseins from cow, sheep, and goat. Allergy. (1997) 52:2938. doi: 10.1111/j.1398-9995.1997.tb00993.x

88. Martín TM, De La Hoz Caballer B, Lizana FM, Mendiola RG, Montano $\mathrm{PP}$, Cano MS. Selective allergy to sheep's and goat's milk proteins. Allergol Immunopathol. (2004) 32:39-42. doi: 10.1157/13057769

89. Ah-Leung S, Bernard H, Bidat E, Paty E, Rance F, Scheinmann P, et al. Allergy to goat and sheep milk without allergy to cow's milk. Allergy. (2006) 61:1358-65. doi: 10.1111/j.1398-9995.2006.01193.x

90. Bevilacqua C, Martin P, Candalh C, Fauquant J, Piot M, Roucayrol A-M, et al. Goats' milk of defective as1-casein genotype decreases intestinal and systemic sensitization to $\beta$-lactoglobulin in guinea pigs. J Dairy Res. (2001) 68:217-27. doi: 10.1017/S0022029901004861

91. Rutherfurd SM, Fanning AC, Miller BJ, Moughan PJ. Protein digestibilitycorrected amino acid scores and digestible indispensable amino acid scores differentially describe protein quality in growing male rats. J Nutr. (2015) 145:372-9. doi: 10.3945/jn.114.195438

92. Bos C, Mahé S, Gaudichon C, Benamouzig R, Gausserès N, Luengo $\mathrm{C}$, et al. Assessment of net postprandial protein utilization of $15 \mathrm{~N}$ labelled milk nitrogen in human subjects. Br J Nutr. (1999) 81:221-6. doi: $10.1017 /$ S0007114599000410

93. Mahe S, Roos N, Benamouzig R, Davin L, Luengo C, Gagnon L, et al. Gastrojejunal kinetics and the digestion of [15N] beta-lactoglobulin and casein in humans: the influence of the nature and quantity of the protein. Am J Clin Nutr. (1996) 63:546-52. doi: 10.1093/ajen/63.4.546

94. Boirie Y, Dangin M, Gachon P, Vasson M-P, Maubois J-L, Beaufrère B. Slow and fast dietary proteins differently modulate postprandial protein accretion. Proc Natl Acad Sci USA. (1997) 94:14930-5. doi: 10.1073/pnas.94.26. 14930

95. Dangin M, Boirie Y, Garcia-Rodenas C, Gachon P, Fauquant J, Callier P, et al. The digestion rate of protein is an independent regulating factor of postprandial protein retention. Am J Physiol Endocrinol Metab. (2001) 280:E340-8. doi: 10.1152/ajpendo.2001.280.2.E340

96. Dangin $M$, Boirie $Y$, Guillet $C$, Beaufrère $B$. Influence of the protein digestion rate on protein turnover in young and elderly subjects. J Nutr. (2002) 132:3228S-33S. doi: 10.1093/jn/131.10.3228S

97. Pennings B, Boirie Y, Senden JM, Gijsen AP, Kuipers H, van Loon, et al. Whey protein stimulates postprandial muscle protein accretion more effectively than do casein and casein hydrolysate in older men. Am J Clin Nutr. (2011) 93:997-1005. doi: 10.3945/ajcn.110.008102

98. Fruhbeck G. Slow and fast dietary proteins. Nature. (1998) 391:843-5. doi: 10.1038/35993

99. Ye A, Roy D, Singh H. Structural changes to milk protein products during gastrointestinal digestion. In: Boland M, Singh H, editors. Milk Proteins. 3rd Edn. New York, NY: Academic Press (2020). p. 671-700. doi: 10.1016/B978-0-12-815251-5.00019-0 
100. Mulet-Cabero A-I, Mackie AR, Brodkorb A, Wilde PJ. Dairy structures and physiological responses: a matter of gastric digestion. Crit Rev Food Sci Nutr. (2020). doi: 10.1080/10408398.2019.1707159. [Epub ahead of print].

101. Henschel MJ, Newport MJ, Parmar V. Gastric proteases in the human infant. Neonatology. (1987) 52:268-72. doi: 10.1159/000242719

102. Moschopoulou E. Characteristics of rennet and other enzymes from small ruminants used in cheese production. Small Rumin Res. (2011) 101:188-95. doi: 10.1016/j.smallrumres.2011.09.039

103. Guinee TP, Wilkinson MG. Rennet coagulation and coagulants in cheese manufacture. Int J Dairy Technol. (1992) 45:94-104. doi: 10.1111/j.1471-0307.1992.tb01791.x

104. Júnior BRCL, Tribst AAL, Cristianini M. High pressure homogenization of porcine pepsin protease: effects on enzyme activity, stability, milk coagulation profile and gel development. PLoS ONE. (2015) 10:e0125061. doi: 10.1371/journal.pone.0125061

105. Crabbe MJC. Rennets: general and molecular aspects. In: Fox PF, McSweeney PLH, Cogan TM, Guinee TP, editors. Cheese: Chemistry, Physics and Microbiology-Volume 1: General Aspects. 3rd Edn. Oxford: Academic Press (2004). p. 19-45. doi: 10.1016/S1874-558X(04)80061-7

106. Piper D, Fenton BH. pH stability and activity curves of pepsin with special reference to their clinical importance. Gut. (1965) 6:506-8. doi: 10.1136/gut.6.5.506

107. Ye A, Cui J, Dalgleish D, Singh, H. Formation of a structured clot during the gastric digestion of milk: impact on the rate of protein hydrolysis. Food Hydrocolloids. (2016) 52:478-86. doi: 10.1016/j.foodhyd.2015.07.023

108. Nakai S, Li-Chan E. Effect of clotting in stomachs of infants on protein digestibility of milk. Food Microstruct. (1987) 6:161-70.

109. Mason S. Some aspects of gastric function in the newborn. Arch Dis Child. (1962) 37:387-91. doi: 10.1136/adc.37.194.387

110. de Oliveira SC, Bellanger A, Ménard O, Pladys P, Le Gouar Y, Dirson E, et al. Impact of human milk pasteurization on gastric digestion in preterm infants: a randomized controlled trial. Am J Clin Nutr. (2017) 105:379-90. doi: 10.3945/ajcn.116.142539

111. Moughan PJ, Rowan A. The pig as a model animal for human nutrition research. Proc Nutr Soc NZ. (1989) 14:116-23. doi: 10.1146/annurev.nu.07.070187.002045

112. Moughan PJ, Cranwell P, Darragh A, Rowan A. The domestic pig as a model animal for studying digestion in humans. Eur Assoc Anim Prod. (1994) 80:389.

113. Moughan PJ, Birtles M, Cranwell P, Smith W, Pedraza M. The piglet as a model animal for studying aspects of digestion and absorption in milk-fed human infants. World Rev Nutr Diet. (1992) 67:40-113. doi: $10.1159 / 000419461$

114. Moughan PJ, Pedraza M, Smith WC, Williams M, Wilson MN. An evaluation with piglets of bovine milk, hydrolyzed bovine milk, and isolated soybean proteins included in infant milk formulas. I. effect on organ development, digestive enzyme activities, and amino acid digestibility. J Pediatr Gastroenterol Nutr. (1990) 10:385-94. doi: 10.1097/00005176-199004000-00020

115. Moughan PJ, Cranwell PD, Smith WC. An evaluation with piglets of bovine milk, hydrolyzed bovine milk, and isolated soybean proteins included in infant milk forumlas. II. stomach-emptying rate and the postprandial change in gastric $\mathrm{pH}$ and milk-clotting enzyme activity. J Pediatr Gastroenterol Nutr. (1991) 12:253-9. doi: 10.1097/00005176-199102000-00019

116. Darragh AJ, Moughan PJ. The amino acid composition of human milk corrected for amino acid digestibility. Br J Nutr. (1998) 80:25-34. doi: 10.1017/S0007114598001731

117. Washburn RM, Jones $\mathrm{CH}$. Studies of the values of different grades of milk in infant feeding. Vermont Agric Exp Station Bull. (1916) 195:94-101. Available online at: https://babel.hathitrust.org/cgi/pt?id=uiug. 30112019892352\&view=1up\&seq=11

118. Braude R, Newport MJ, Porter JW. Artificial rearing of pigs: 2. The time course of milk protein digestion proteolytic enzyme secretion in the 28-day-old pig. Br J Nutr. (1970) 24:827-42. doi: 10.1079/BJN197 00086

119. Decuypere JA, Bossuyt R, Henderickx HK. Gastric secretion in suckling pigs and early-weaned pigs given a dry cow's-milk formula ad lib. Br J Nutr. (1978) 40:91-102. doi: 10.1079/BJN19780099
120. Lichan E, Nakai S. Rennin modification of bovine casein to simulate human casein composition - effect on acid clotting and hydrolysis by pepsin. Can Inst Food Sci Technol J. (1988) 21:200-8. doi: 10.1016/S0315-5463(88)70777-4

121. Lichan E, Nakai S. Enzymic dephosphorylation of bovine casein to improve acid clotting properties and digestibility for infant formula. J Dairy Res. (1989) 56:381-90. doi: 10.1017/S0022029900028843

122. Blakeborough P, Gurr MI, Salter DN. Digestion of the zinc in human milk, cow's milk and a commercial babyfood: some implications for human infant nutrition. Br J Nutr. (1986) 55:209-17. doi: 10.1079/BJN19860027

123. Uniacke-Lowe T, Fox PF. Equid milk. In: Fuquay JW, Fox PF, McSweeney PLH, editors. Encyclopedia of Dairy Sciences. Vol. 3, 2nd Edn. San Diego, CA: Academic Press (2011). p. 518-29. doi: 10.1016/B978-0-12-374407-4.00318-6

124. Iannella G. Donkey cheese made through pure camel chymosin. Afr J Food Sci. (2015) 9:421-5. doi: 10.5897/AJFS2015.1322

125. Charfi I, Rezouga F, Makhlouf A, Bornaz S. The behaviour of Arabian donkey milk during acidification compared to bovine milk. Int J Dairy Technol. (2018) 71:439-45. doi: 10.1111/1471-0307.12447

126. Kamal M, Foukani M, Karoui R. Rheological and physical properties of camel and cow milk gels enriched with phosphate and calcium during acid-induced gelation. J Food Sci Technol. (2017) 54:439-46. doi: 10.1007/s13197-016-2480-9

127. Wang Y, Eastwood B, Yang Z, de Campo L, Knott R, Prosser C, et al. Rheological and structural characterization of acidified skim milks and infant formulae made from cow and goat milk. Food Hydrocolloids. (2019) 96:161-70. doi: 10.1016/j.foodhyd.2019.05.020

128. Ould Eleya MM, Desobry Banon S, Vetier N Hardy J. Rheological study of acid gels from cow, goat and sheep milks. Lait. (1998) 78:453-9. doi: 10.1051/lait:1998443

129. Gamble JA, Besley AK, Ellis NR. Composition and properties of goat's milk as compared with cow's milk. US Dept Agric Tech Bull. (1939) 671:1-72.

130. Genene A, Hansen EB, Eshetu M, Hailu Y, Ipsen R. Effect of heat treatment on denaturation of whey protein and resultant rennetability of camel milk. LWT. (2019) 101:404-9. doi: 10.1016/j.lwt.2018.11.047

131. Jasińska B. The comparison of pepsin and trypsin action on goat, cow, mare and human caseins. Rocz Akad Med Bialymst. (1995) 40:486-93.

132. Hodgkinson AJ, Wallace OAM, Boggs I, Broadhurst M, Prosser CG. Gastric digestion of cow and goat milk: impact of infant and young child in vitro digestion conditions. Food Chem. (2018) 245:275-81. doi: 10.1016/j.foodchem.2017.10.028

133. Tagliazucchi D, Martini S, Shamsia S, Helal A, Conte A. Biological activities and peptidomic profile of in vitro-digested cow, camel, goat and sheep milk. Int Dairy J. (2018) 81:19-27. doi: 10.1016/j.idairyj.2018.01.014

134. Tagliazucchi D, Shamsia S, Helal A, Conte A. Angiotensinconverting enzyme inhibitory peptides from goats' milk released by in vitro gastro-intestinal digestion. Int Dairy J. (2017) 71:6-16. doi: 10.1016/j.idairyj.2017.03.001

135. Rutella GS, Solieri L, Martini S, Tagliazucchi, D. Release of the antihypertensive tripeptides valine-proline-proline and isoleucine-prolineproline from bovine milk caseins during in vitro gastrointestinal digestion. J Agric Food Chem. (2016) 64:8509-15. doi: 10.1021/acs.jafc.6b03271

136. Maathuis A, Havenaar R, He T, Bellmann S. Protein digestion and quality of goat and cow milk infant formula and human milk under simulated infant conditions. J Pediatr Gastroenterol Nutr. (2017) 65:661-6. doi: 10.1097/MPG.0000000000001740

137. Almaas H, Cases A-L, Devold TG, Holm H, Langsrud T, Aabakken L, et al. In vitro digestion of bovine and caprine milk by human gastric and duodenal enzymes. Int Dairy J. (2006) 16:961-8. doi: 10.1016/j.idairyj.2005. 10.029

138. El-Zahar K, Sitohy M, Choiset Y, Métro F, Haertlé T, Chobert J-M. Peptic hydrolysis of ovine $\beta$-lactoglobulin and $\alpha$-lactalbumin. exceptional susceptibility of native ovine $\beta$-lactoglobulin to pepsinolysis. Int Dairy J. (2005) 15:17-27. doi: 10.1016/j.idairyj.2004.06.002

139. Inglingstad RA, Devold TG, Eriksen EK, Holm H, Jacobsen M, Liland KH, et al. Comparison of the digestion of caseins and whey proteins in equine, bovine, caprine and human milks by human gastrointestinal enzymes. Dairy Sci Technol. (2010) 90:549-63. doi: 10.1051/dst/2010018 
140. Mros S, Carne A, Ha M, Bekhit AE-D, Young W, McConnell, et al. Comparison of the bioactivity of whole and skimmed digested sheep milk with that of digested goat and cow milk in functional cell culture assays. Small Rumin Res. (2017) 149:202-8. doi: 10.1016/j.smallrumres.2017.02.018

141. Milan AM, Hodgkinson AJ, Mitchell SM, Prodhan UK, Prosser CG, Carpenter EA, et al. Digestive responses to fortified cow or goat dairy drinks: a randomised controlled trial. Nutrients. (2018) 10:1492. doi: $10.3390 /$ nu10101492

142. Mills D. The in vitro buffering capacity of soluble paracetamol. Anaesthesia. (1989) 44:967-9. doi: 10.1111/j.1365-2044.1989.tb09197.x

143. Vaisman N, Reuven Y, Uzi M, Georgi G, Boehm G. Camel's milk and gastric emptying. Clin Nutr. (2006) 25:622-5. doi: 10.1016/j.clnu.2006.02.011

144. Kong F, Singh RP. A human gastric simulator (HGS) to study food digestion in human stomach. J Food Sci. (2010) 75:E627-35. doi: 10.1111/j.1750-3841.2010.01856.x

145. Ye A, Liu W, Cui J, Kong X, Roy D, Kong Y, et al. Coagulation behaviour of milk under gastric digestion: effect of pasteurization and ultra-high temperature treatment. Food Chem. (2019) 286:216-25. doi: 10.1016/j.foodchem.2019.02.010

146. Schorsch C, Wilkins DK, Jones MG, Norton IT. Gelation of casein-whey mixtures: effects of heating whey proteins alone or in the presence of casein micelles. J Dairy Res. (2001) 68:471-81. doi: 10.1017/S0022029901004915

147. Dannenberg F, Kessler HG. Reaction kinetics of the denaturation of whey proteins in milk. J Food Sci. (1988) 53:258-63. doi: 10.1111/j.1365-2621.1988.tb10223.x

148. Kaufmann W. Influences of different technological treatments of milk on the digestion in the stomach. VI. estimation of amino acid and urea concentrations in the blood: conclusions regarding the nutritional evaluation. Milchwissenschaft. (1984) 39:281-4.

149. Lacroix M, Bon C, Bos C, Léonil J, Benamouzig R, Luengo C, et al. Ultra high temperature treatment, but not pasteurization, affects the postprandial kinetics of milk proteins in humans. J Nutr. (2008) 138:2342-7. doi: 10.3945/jn.108.096990

150. Doan FJ. Soft curd milk: a critical review of the literature. J Dairy Sci. (1938) 21:739-56. doi: 10.3168/jds.S0022-0302(38)93028-0

151. Ye A, Cui J, Dalgleish D, Singh H. The formation and breakdown of structured clots from whole milk during gastric digestion. Food Funct. (2016) 7:4259-66. doi: 10.1039/C6FO00228E

152. Ye A, Cui J, Dalgleish D, Singh H. Effect of homogenization and heat treatment on the behavior of protein and fat globules during gastric digestion of milk. J Dairy Sci. (2017) 100:36-47. doi: 10.3168/jds.201611764

153. Mulet-Cabero A-I, Mackie AR, Wilde PJ, Fenelon MA, Brodkorb A. Structural mechanism and kinetics of in vitro gastric digestion are affected by process-induced changes in bovine milk. Food Hydrocolloids. (2019) 86:172-83. doi: 10.1016/j.foodhyd.2018.03.035

154. Mulet-Cabero A-I, Torcello-Gómez A, Saha S, Mackie AR, Wilde PJ, Brodkorb A. Impact of caseins and whey proteins ratio and lipid content on in vitro digestion and ex vivo absorption. Food Chem. (2020) 319:126514. doi: 10.1016/j.foodchem.2020.126514

155. Mulet-Cabero A-I, Egger L, Portmann R, Ménard O, Marze S, Minekus $\mathrm{M}$, et al. A standardised semi-dynamic in vitro digestion method suitable for food - an international consensus. Food Funct. (2020) 11:1702-20. doi: 10.1039/C9FO01293A

156. Ménard O, Bourlieu C, De Oliveira SCS, Dellarosa N, Laghi L, Carrière F, et al. A first step towards a consensus static in vitro model for simulating full-term infant digestion. Food Chem. (2018) 240:338-45. doi: 10.1016/j.foodchem.2017.07.145

157. Bourlieu C, Menard O, De La Chevasnerie A, Sams L, Rousseau F, Madec $\mathrm{MN}$, et al. The structure of infant formulas impacts their lipolysis, proteolysis and disintegration during in vitro gastric digestion. Food Chem. (2015) 182:224-35. doi: 10.1016/j.foodchem.2015.03.001

158. Meena S, Rajput Y, Sharma R. Comparative fat digestibility of goat, camel, cow and buffalo milk. Int Dairy J. (2014) 35:153-6. doi: 10.1016/j.idairyj.2013.11.009

159. Alférez MJM, Barrionuevo M, López Aliaga I, Lisbona F, Robles JC, Campos MS, et al. Digestive utilization of goat and cow milk fat in malabsorption syndrome. J Dairy Res. (2001) 68:451-61. doi: 10.1017/S0022029901004903

160. Teng F, Reis MG, Yang L, Ma Y, Day L. Structural characteristics of triacylglycerols contribute to the distinct in vitro gastric digestibility of sheep and cow milk fat prior to and after homogenisation. Food Res Int. (2020) 130:108911. doi: 10.1016/j.foodres.2019.108911

161. Shani-Levi C, Alvito P, Andrés A, Assunção R, Barberá R, Blanquet-Diot S, et al. Extending in vitro digestion models to specific human populations: perspectives, practical tools and bio-relevant information. Trends Food Sci Technol. (2017) 60:52-63. doi: 10.1016/j.tifs.2016.10.017

Conflict of Interest: The authors declare that the research was conducted in the absence of any commercial or financial relationships that could be construed as a potential conflict of interest.

Copyright $\odot 2020$ Roy, Ye, Moughan and Singh. This is an open-access article distributed under the terms of the Creative Commons Attribution License (CC BY). The use, distribution or reproduction in other forums is permitted, provided the original author(s) and the copyright owner(s) are credited and that the original publication in this journal is cited, in accordance with accepted academic practice. No use, distribution or reproduction is permitted which does not comply with these terms. 